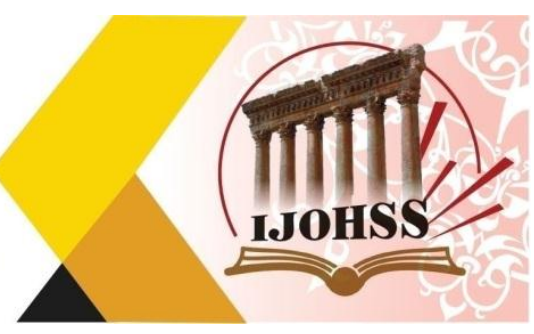

\title{
أصول المنهج التفسيري عند الامام الطحاوي في تفسيره أحكام القرآن
}

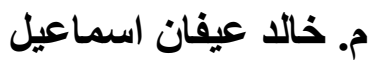

كلية الإمام الاعظم رحمة الله تعالى الجامعةــ العراق

khalidch272@gmail.com البريد الاكتروني

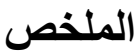

لقد هيأ الله تعالى لهذه الأمة رجالاً صنعو ا رفتها، وبنو ا مفاخر هـا، و أعلو هـا إلى سـامي مجدها، حتى كانت خير

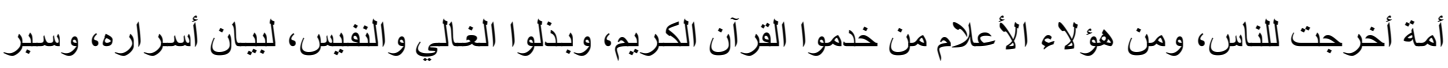
أعماق اغو اره، ومن أبرزهم الإمام (أبو جعفر احمد بن محمد الطحاوي تاءت 321هــ)، ذللك العالم الجليل، والبحر

$$
\text { وقد الكبير، الذي عرف بتأليفه لكتابه في (تفسير احكام القرآن الكريم). }
$$

أما المبحث الأول: فجعلته في مطلبين، عرضت في المطلب الأول ترجمة موجزة للإمام الطحاوي ، وأما المطلب

$$
\text { الثاني فتناولت فيه منهج الإمام الطحاوي في تفسيره. }
$$

أما المبحث الثاني: فكان في خمس مطالب، و هي الأسس التي اعتمدها في تفسيرهوهي وهي تفسيره القرآن بالقر آن،

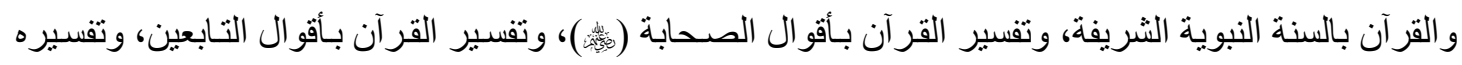
القرآن باللغة.

الكلمات المفتاحية: المنهج التفسيري، الامام الطحاوي، أحكام القرآن. 


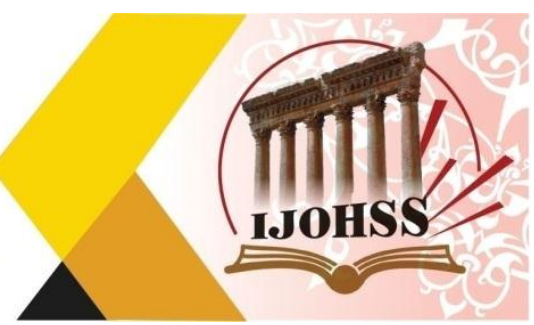

\title{
The Origins of the Exegetical Approach of Imam Al-Tahawi in his Interpretation of the Provisions of the Qur'an
}

\author{
Lect. Khaled Aifan Ismail \\ College of the Great Imam, may God Almighty have mercy on him, University - Iraq \\ Email: khalidch272@gmail.com
}

\begin{abstract}
God Almighty has prepared for this nation men who made its glory, built its glories, and elevated it to the most exalted of its glory, until it was the best nation brought out to people, and among these figures are those who served the Noble Qur'an, and sacrificed the most precious and precious, to explain its secrets, and probe the depths of its depths, and among the most prominent of them is Imam (Abu Jaafar) Ahmed bin Muhammad al-Tahawi, d. $321 \mathrm{AH}$ ), that venerable scholar, and the great sea, who was known for authoring his book (interpretation of the provisions of the Noble Qur'an).

The nature of the research necessitated that I make it an introduction, two chapters, and a conclusion.

As for the first topic: I made it into two demands. In the first requirement, I presented a brief translation of Imam Al-Tahawi, and as for the second requirement, I dealt with Imam Al-Tahawi's approach to his interpretation.

As for the second topic: it was in five demands, which are the foundations that he adopted in his interpretation, namely his interpretation of the Qur'an by the Qur'an, the Qur'an with the honorable Sunnah of the Prophet, the interpretation of the Qur'an by the sayings of the Companions, the interpretation of the Qur'an by the sayings of the followers, and its interpretation of the Qur'an in language.
\end{abstract}

Keywords: exegetical approach, Imam al-Tahawi, provisions of the Qur'an. 


\title{
المبحث الأول \\ حياة الإمام الطحاوي ومنهجه في تفسيره
}

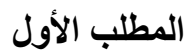 \\ ت ترجمة موجزة للإمام الطداوي
}

هو أحمد بن محنيته ونسبه: بلامة بن سلمة بن عبد الملك بن سلمة الازدي الحجري المصري الطحاوي، الحنفي أبو جعفر (1) ج مون.

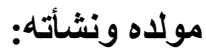
ولد الإمام الطحاوي سنة (239 هـ)، و هذا التاريخ ليس موضع اتفاق بين المؤرخين، و هنالك عدة أقو ال في تعيين السنة التي شهدت وولادة الإمام الطحاوي.

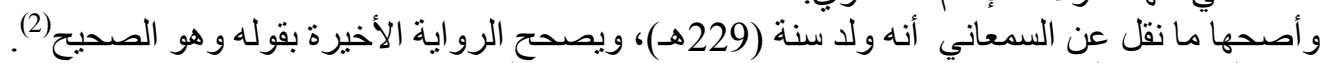

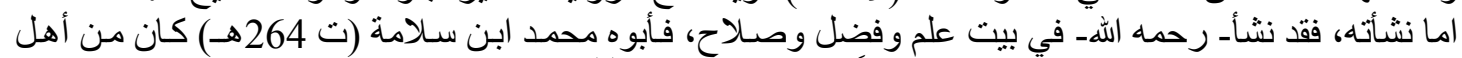

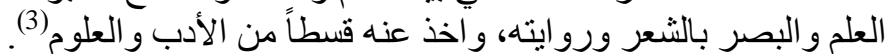

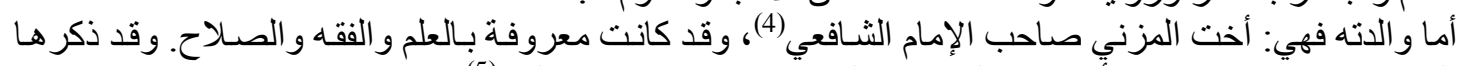

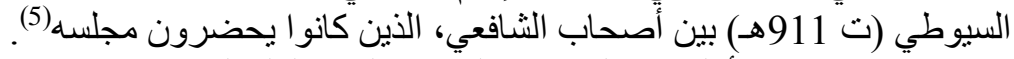
وكان مصدر ثقافته الأولى هو البيت، ثم التحق بحلقات العلى العلم التي كانت تقام

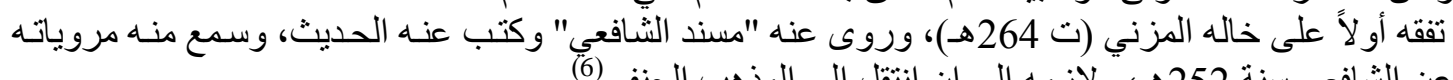

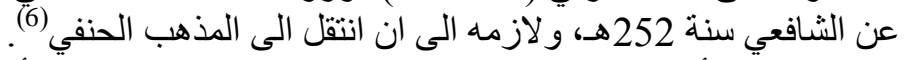

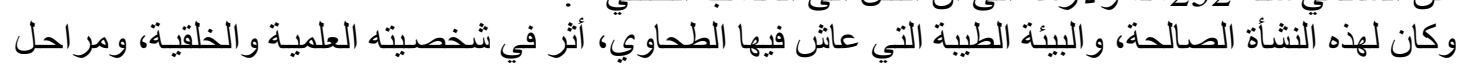

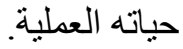

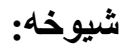

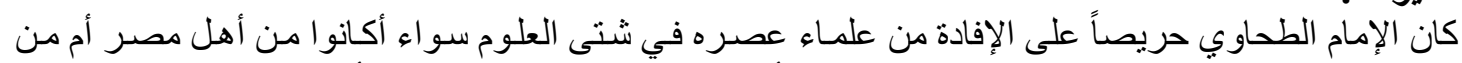

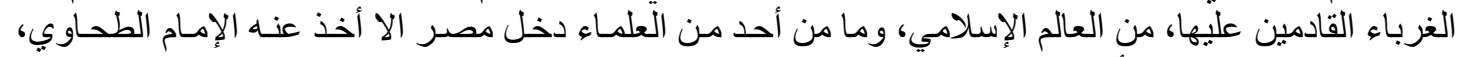

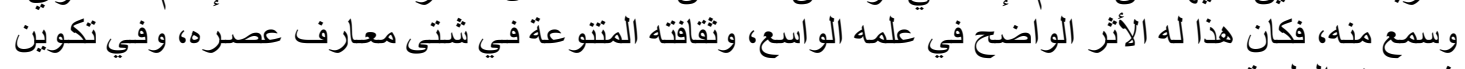
شخصيته العلمية.

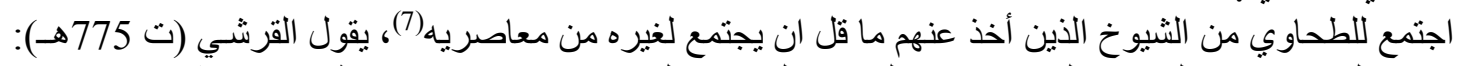

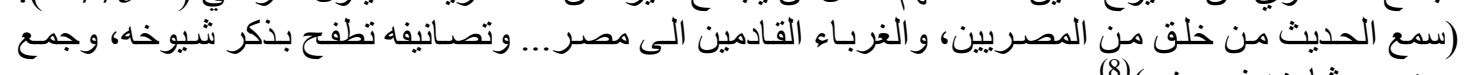

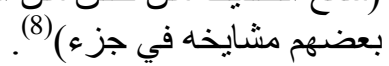

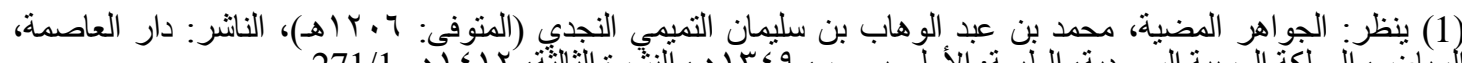

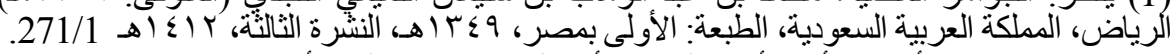

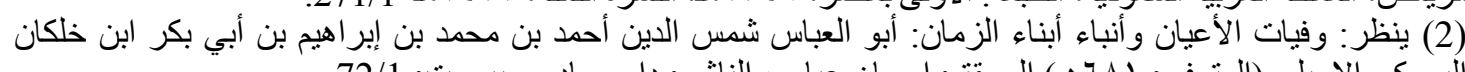

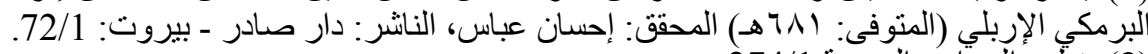

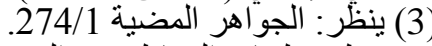

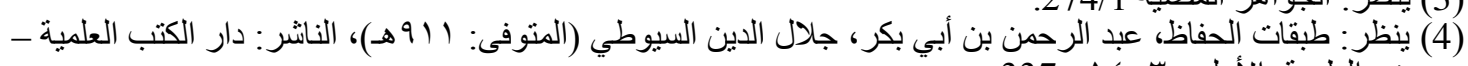

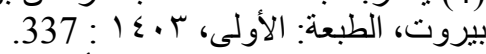

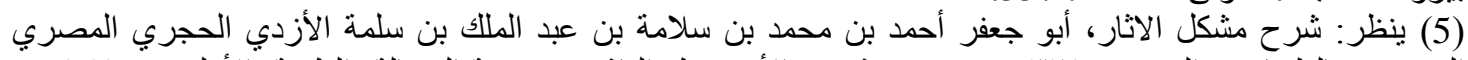

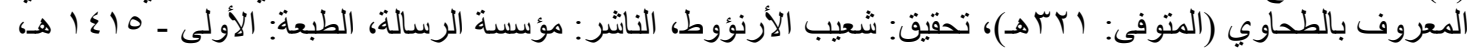




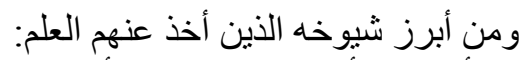

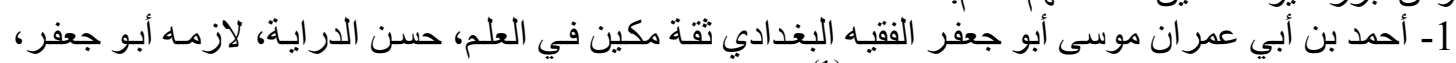

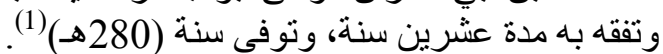

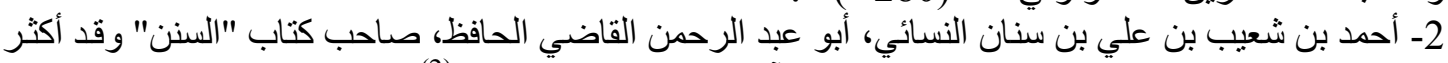

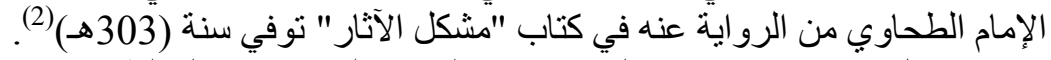

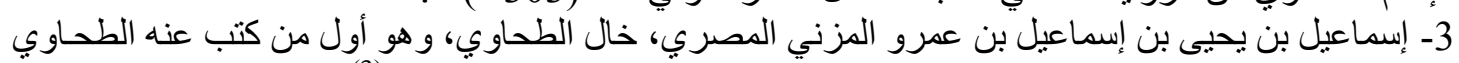

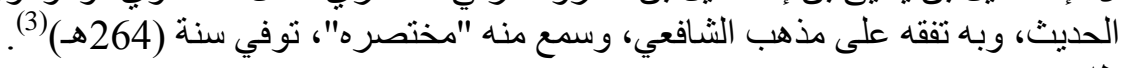
طلابه: اشتهر الإمام الطحاوي وذاع صيته في الآفاق لسعة معرفته بالحديث، و الفقه، و العلوم الأخرى الدينية التي كانت

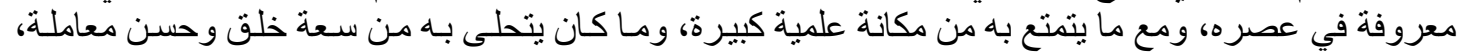

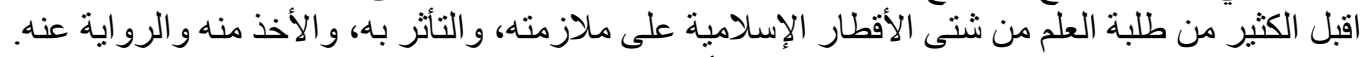

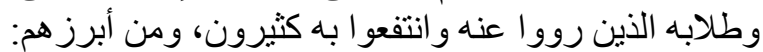

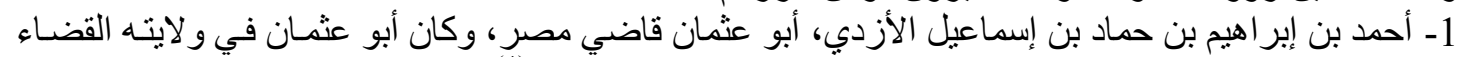

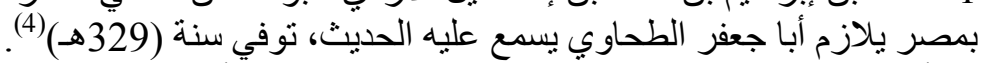

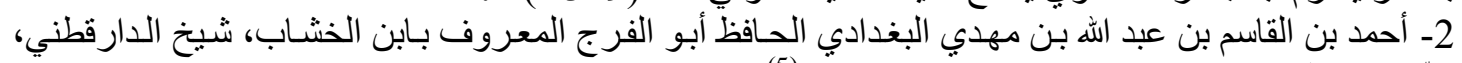

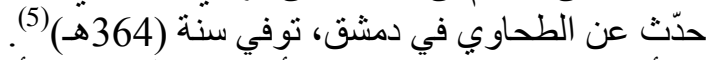

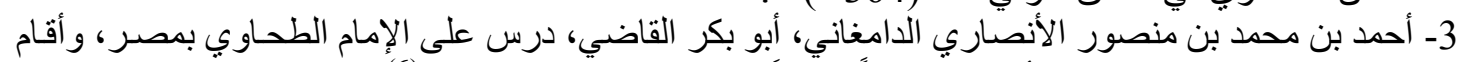

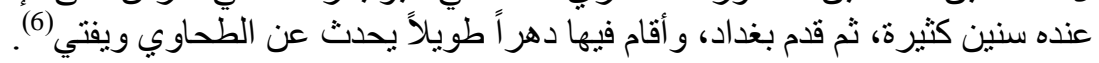

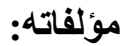
كان الإمام الطحاوي على مستوى عقلي رفيع واطلاع واسع، وثقافة علمية ثرية، فأسهم ذللك في إنتاج علمي

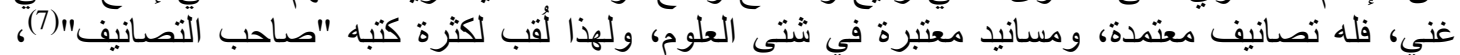

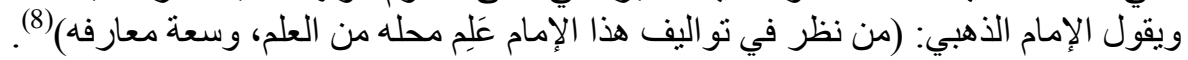

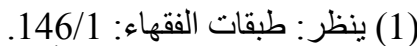

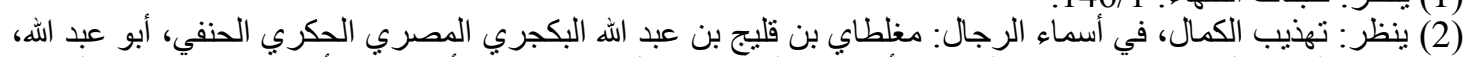

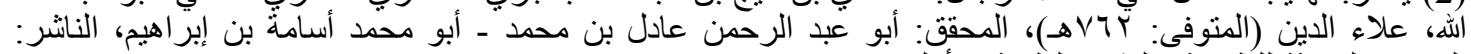

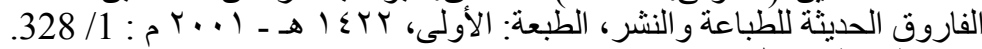
(3) ينظر : طبقات الفقهاء: 109/1، 189.

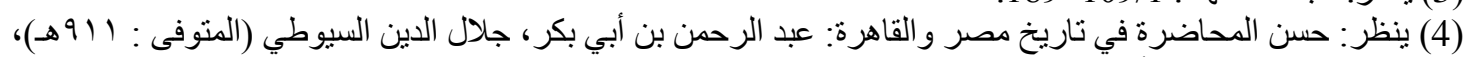

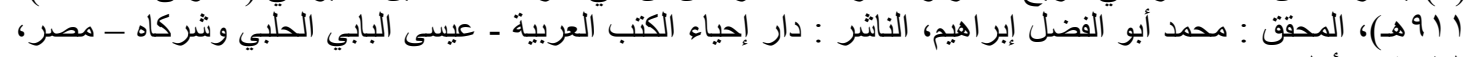

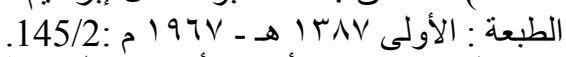

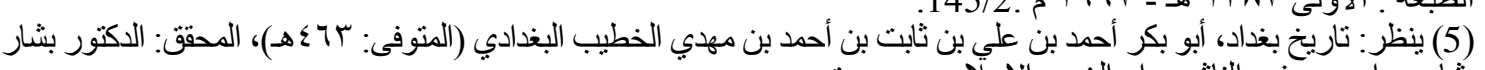

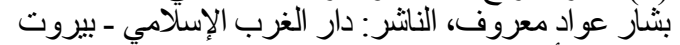

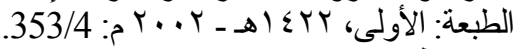

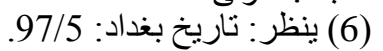

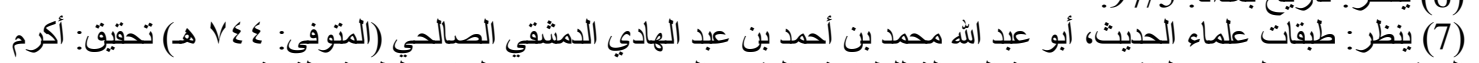

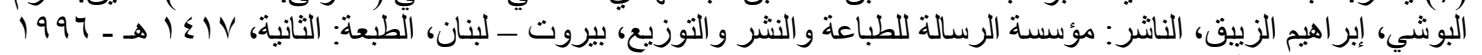

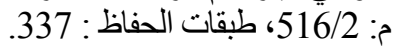
(8) سير اعلام النبلاء ، شمس الدين أبو عبد الله محمد بن أحمد بن عثمان بن قَائماز الذهبي (المنوفى: 748 هـ) المحقق:

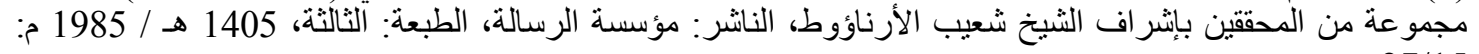




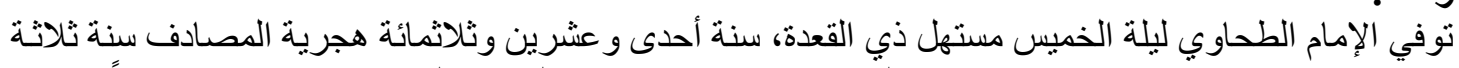

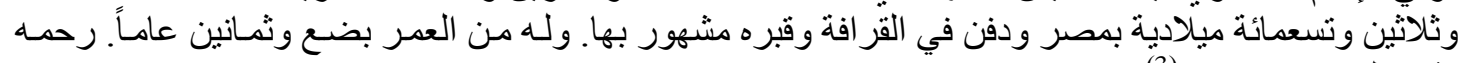

\section{منهج الإمام الطحاوي في تفسيره المباني أحكام القرآن}

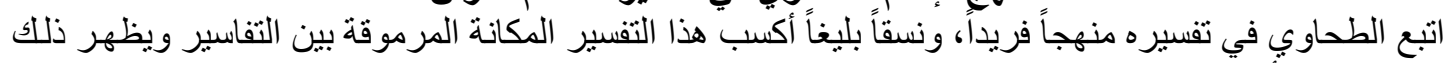

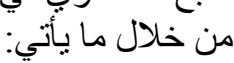

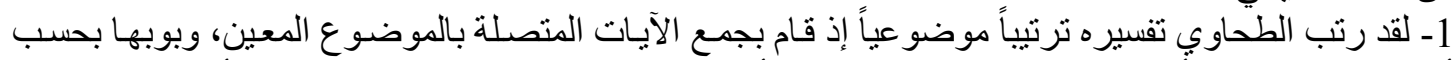

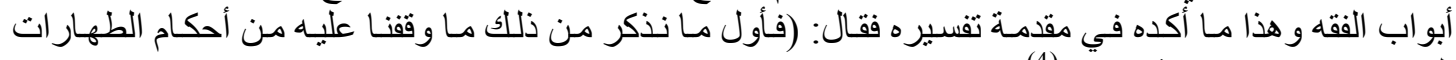

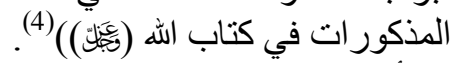

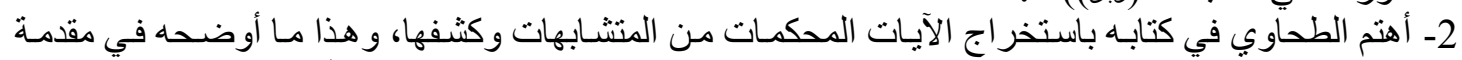

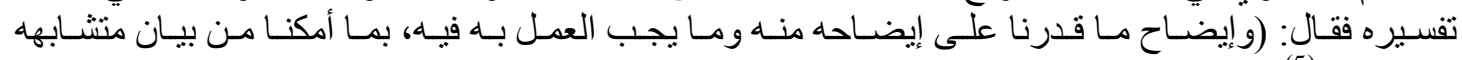

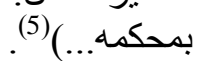
3- و واستعان الطحاوي في تفسيره بالمأثنور من أقو ال الصحابة و التابعين ومـا نقل عنهم من تفسير للآيـة المتعلقة

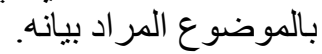

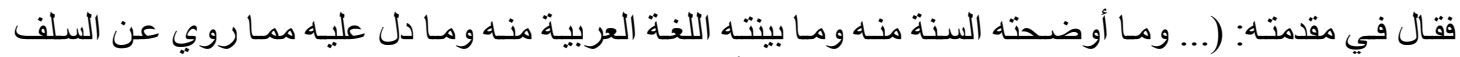

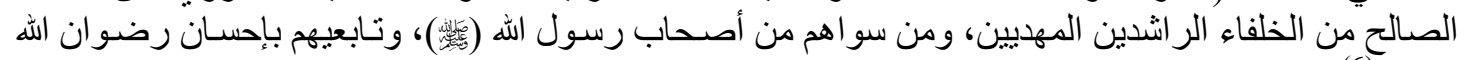
عليهم) (6) 4- و وعنى الطحاوي عناية خاصة بالناسخ و المنسو خ من الآيات و الأحاديث.

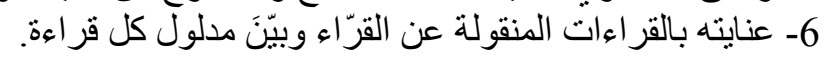

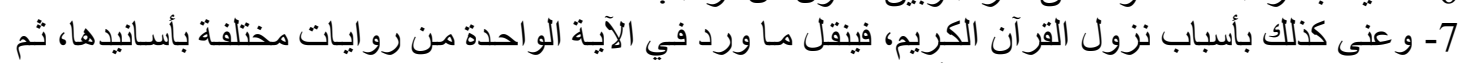
يلحقها بذكر الروايات التي رويت عن عن الأئمة في نوجيه فينل الآية الكريمة.

(1) ينظر: الفهرست، أبو الفرج محمد بن إسحاق بن محمد الوراق البغدادي المعتزلي الثبعي المعروف بابن الثبان النديم

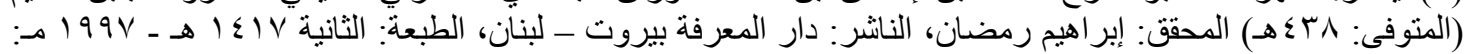

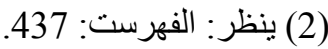

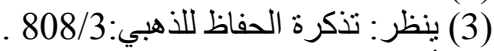
(4) أحكام القر آن الكريم: 66/1. 


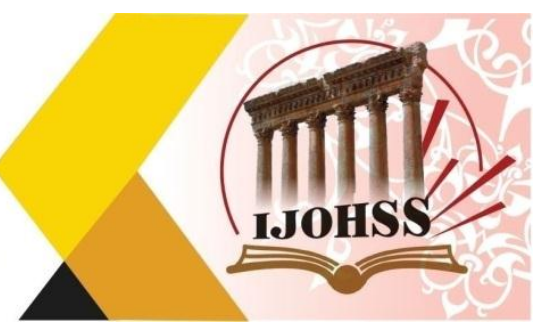
أصول المنهج التفسيري عند الامام الطحاوي

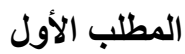 \\ تفسير القرآن بالقرآن
}

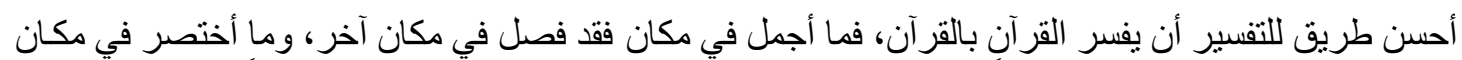

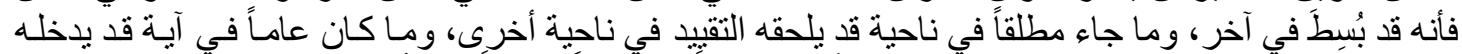

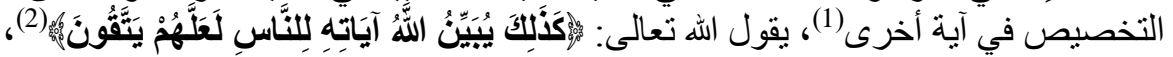

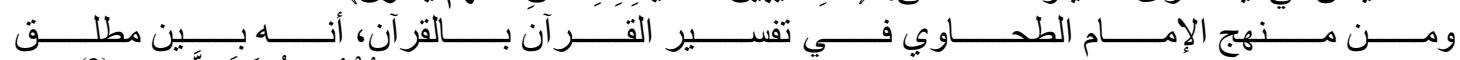

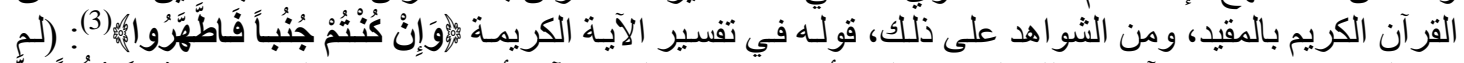

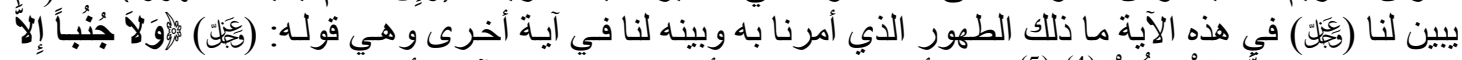

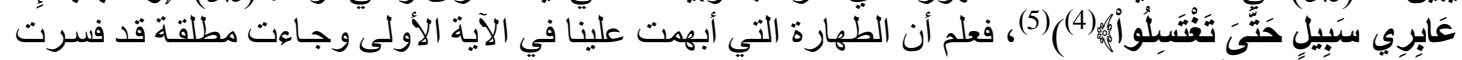

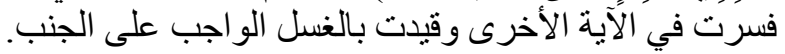

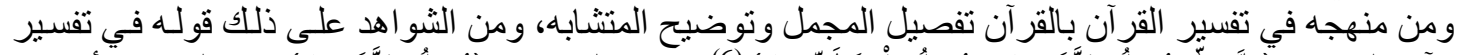

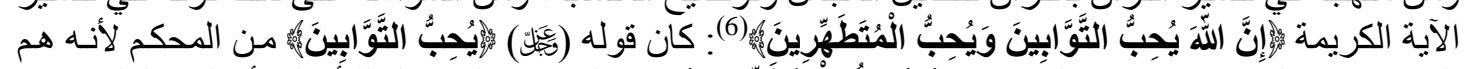

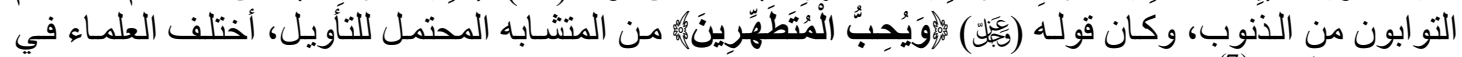

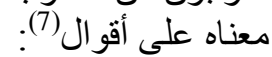

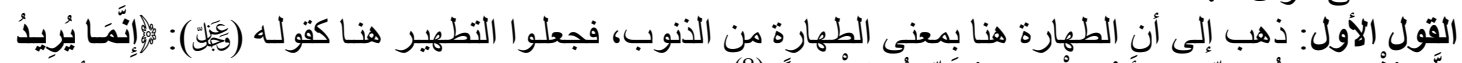

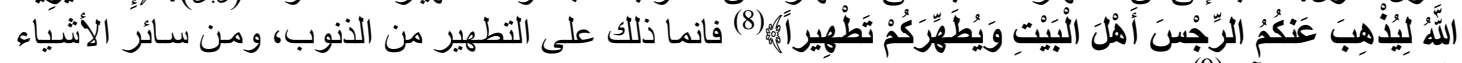

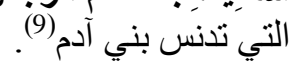

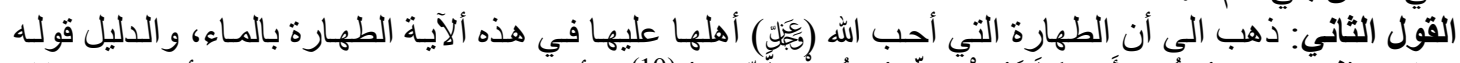

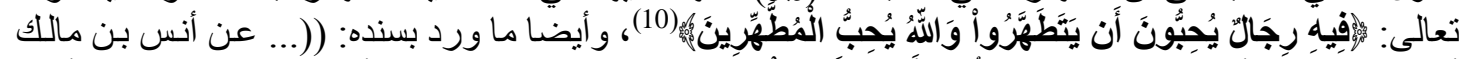

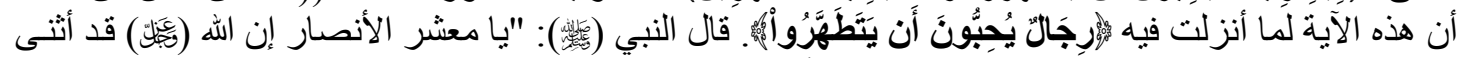

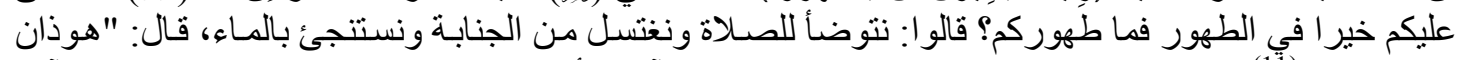

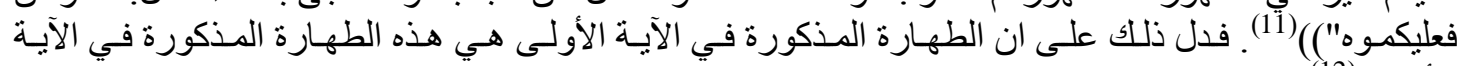
الأخرى (12).

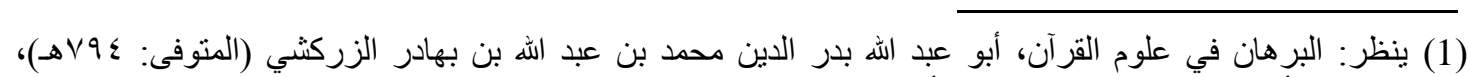

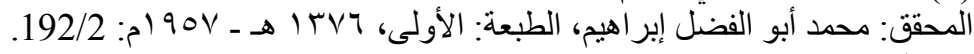

(2) (2) (2) البقرة: 187.

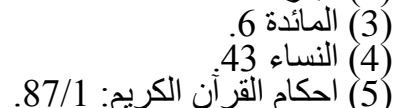

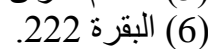

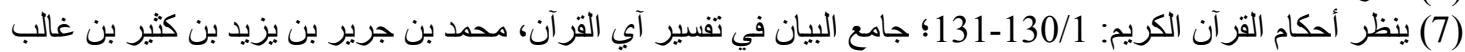

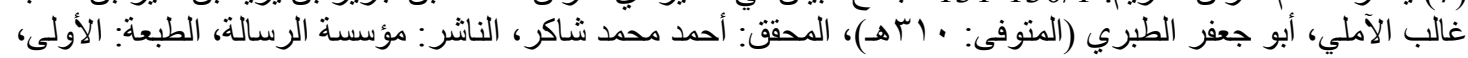

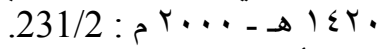

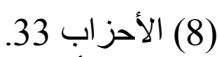

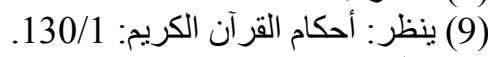

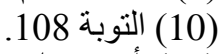

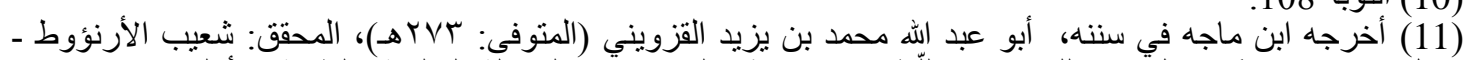

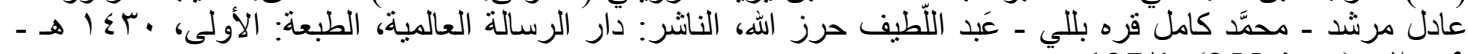

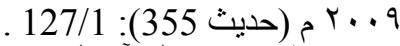

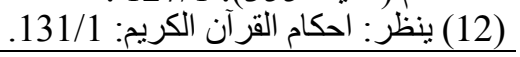




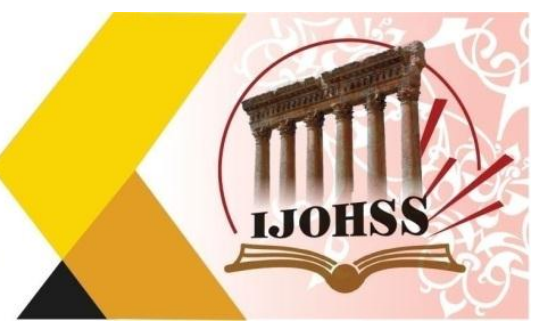

$$
\text { تفسير القرآن بالسنة: النبوية }
$$

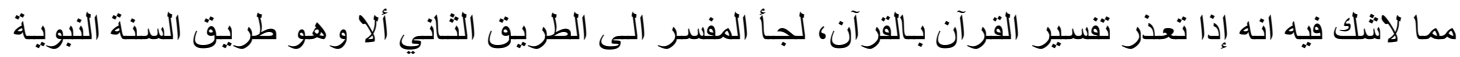

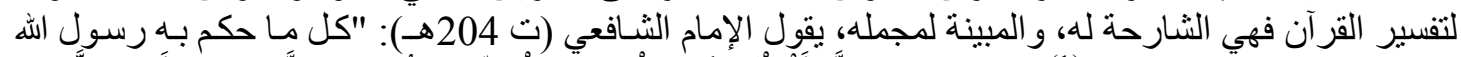

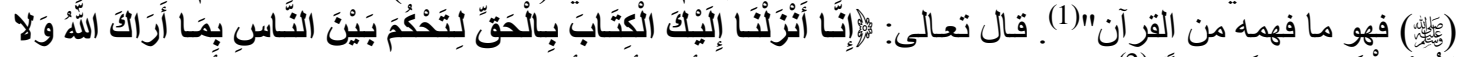

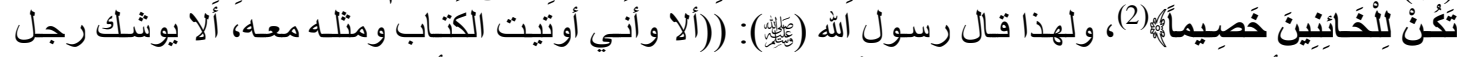

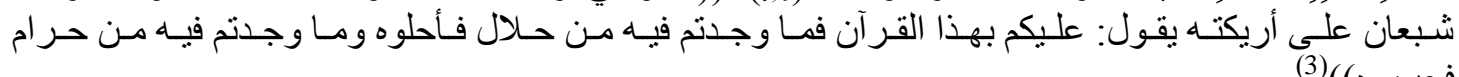

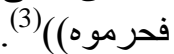

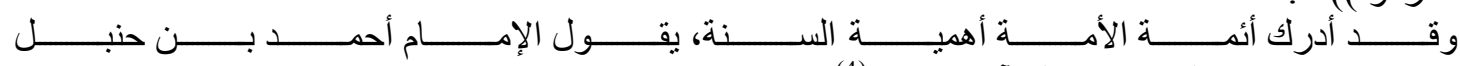

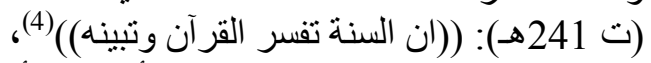

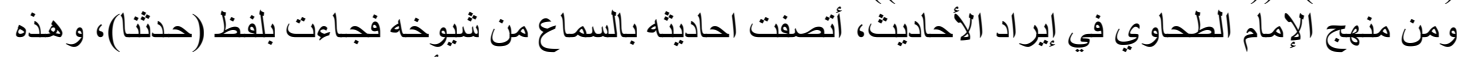

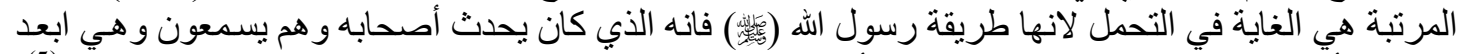

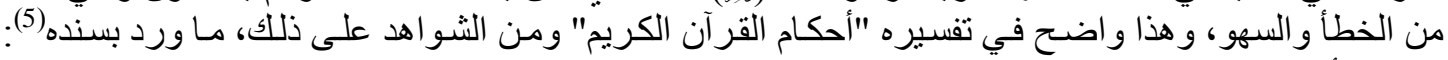

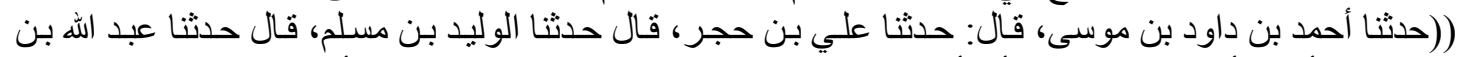

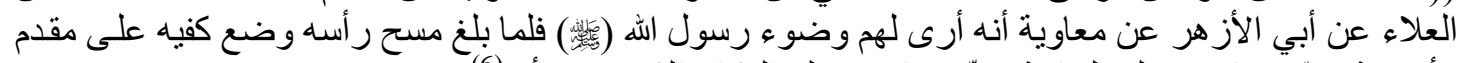

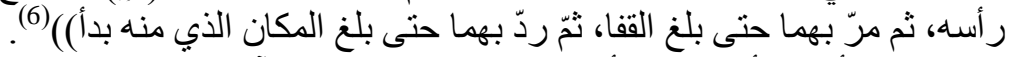

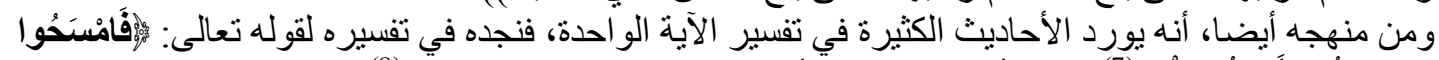

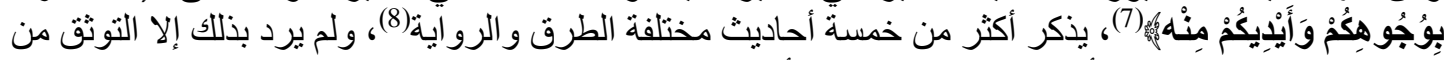

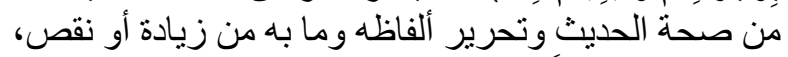

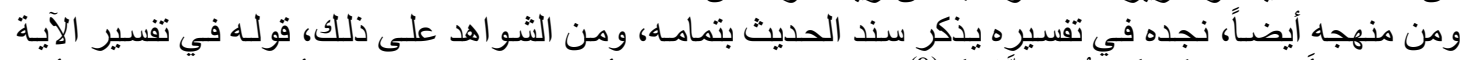

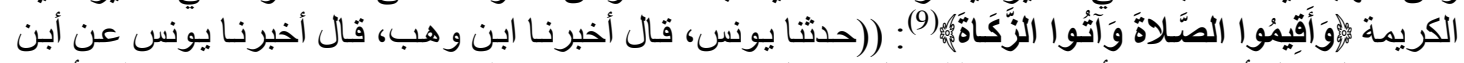

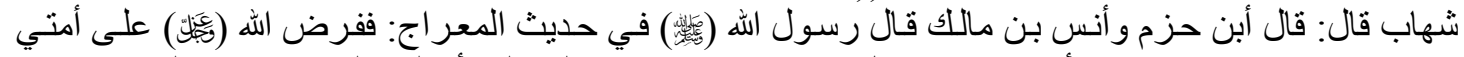

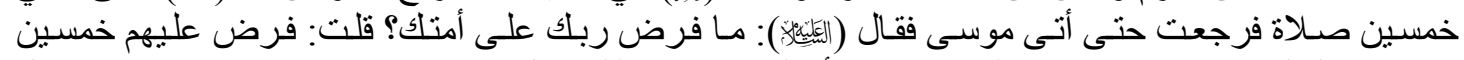

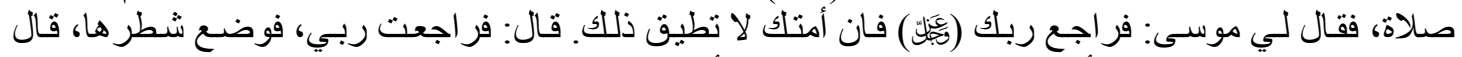

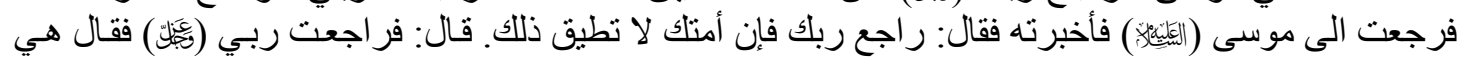

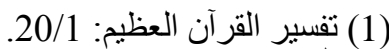

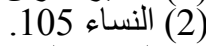

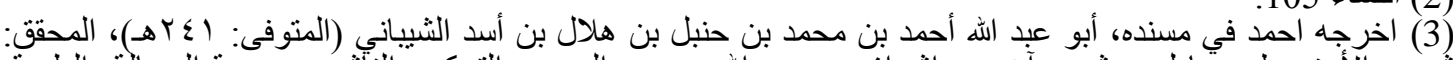

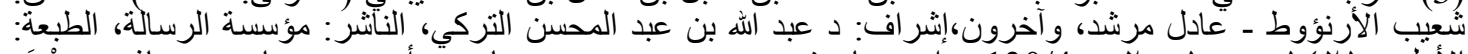

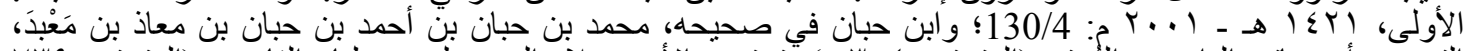

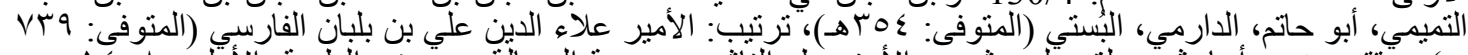

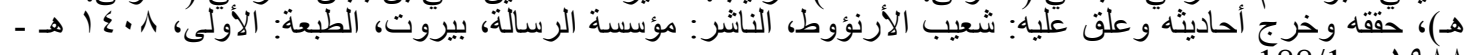
188/1: 1911 (4) (4) مباحث في علم التفسير : 40.

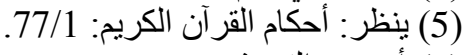

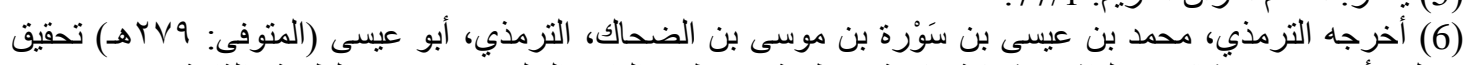

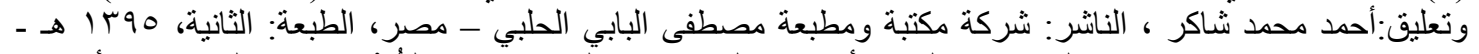

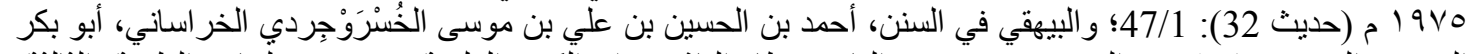
البيهقي (المنوفى: 101 هـ هـ)، المحقق: محمد عبد القادر عطا، النانشر: دار الكتب العلمية، بيروت - لبنان، الطبعة: الثالثة، 


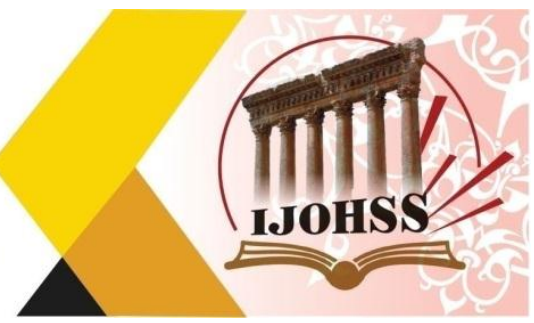

خمس، و هي خمسون لا يبدل القول لاي. قال: فرجعت الى موسى، فقال: ارجع إلى ربك، فقلت قد استحييت من

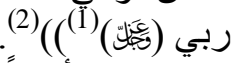

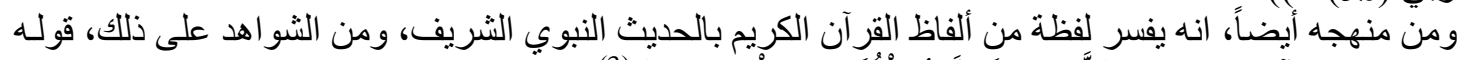

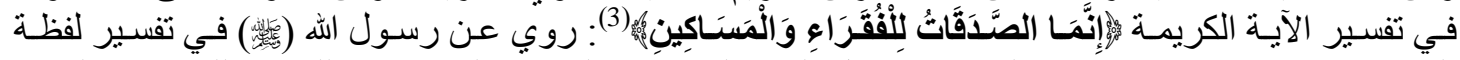

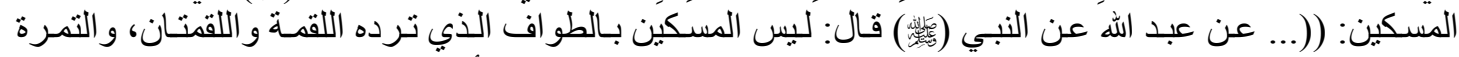

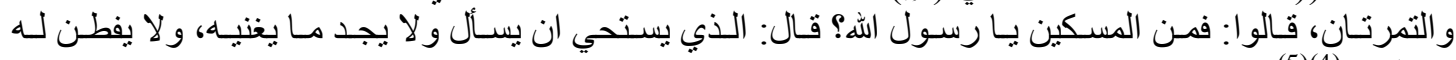

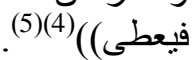

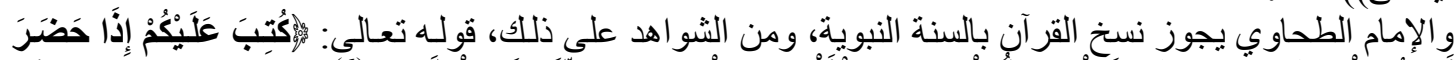

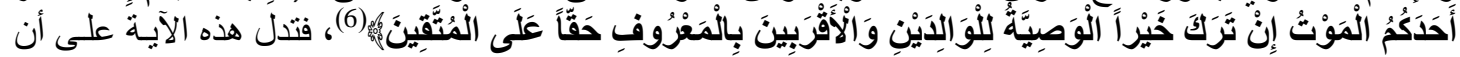

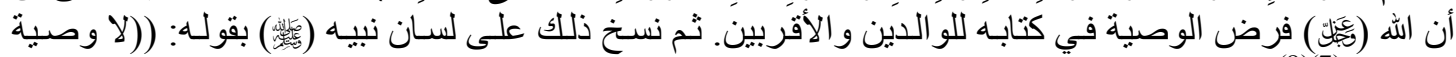

\section{المطلب الثالث}

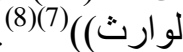

\section{تفسير القرآن بأقوال الصحابة}

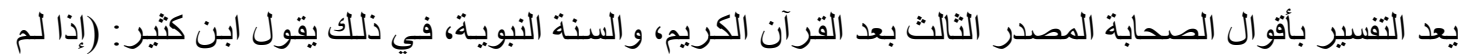

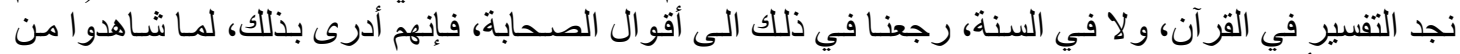

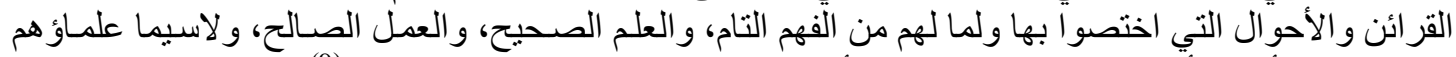

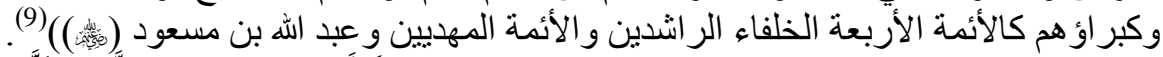

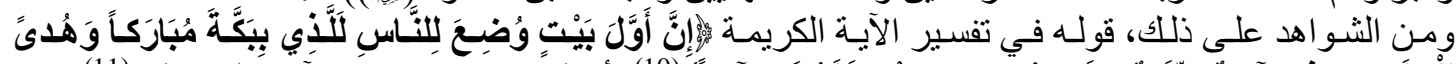

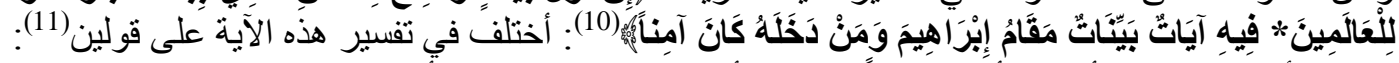

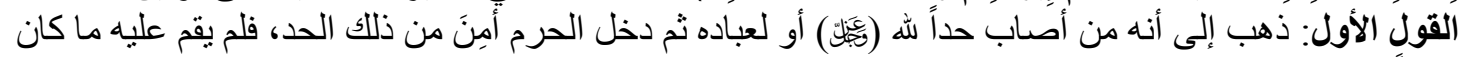

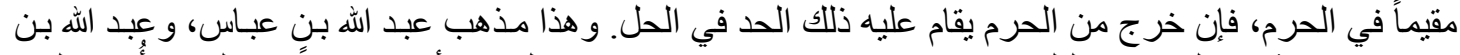

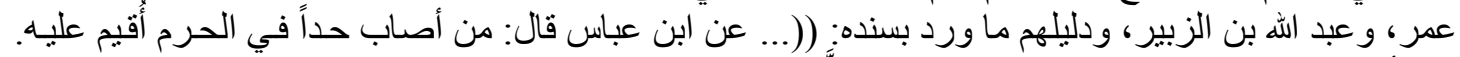

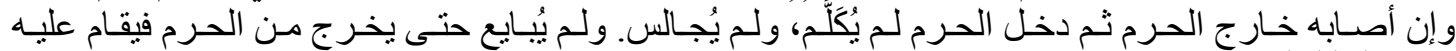

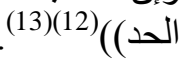

(1) صحيح مسلم، أبو الحسين مسلم بن الحجاج القشبيري النيسابوري، المحقق: نظر بن محمد الفاريابي أبو قتيبة، دار

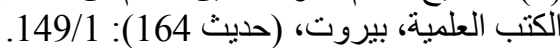
(2) (2) أحكام القرآن الكريم: 166/1) (3) التوبة 60 (3)

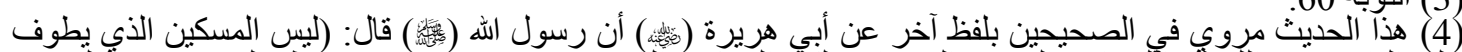

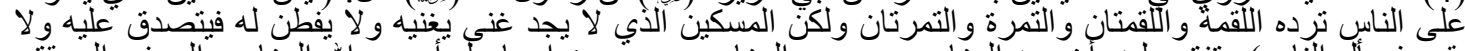

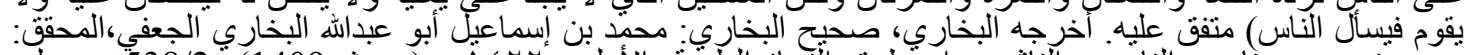

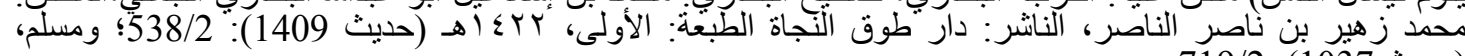

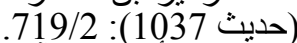

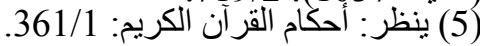

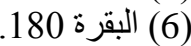
(7) (7) أخرجه البخاري، (حليث 1896) 2596): 1008/3.

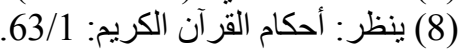
(9) تفسير القرآن العظيم: 22/1؛ وينظر : البران البرهان في علوم القر آن (طبعة دار الفكر ): 192/2.

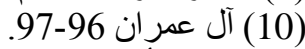

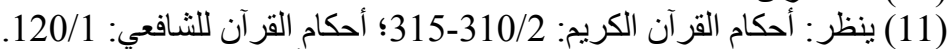

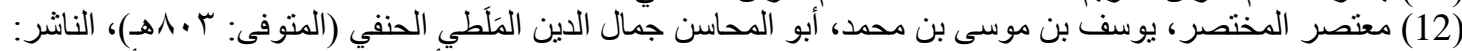

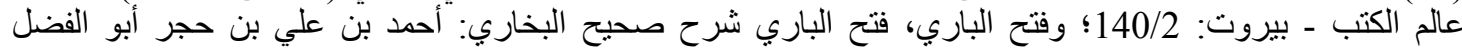

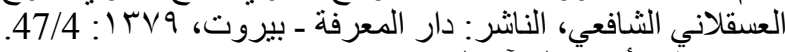
310/2. 


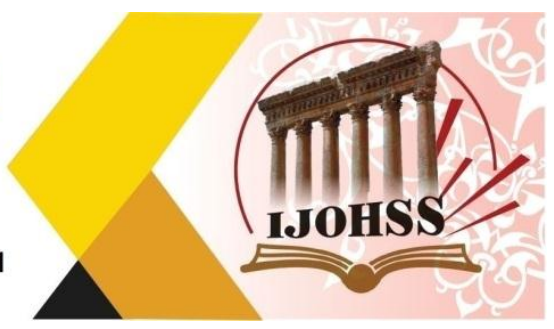

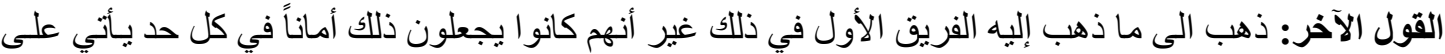

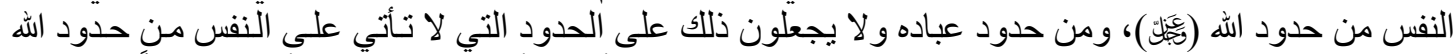

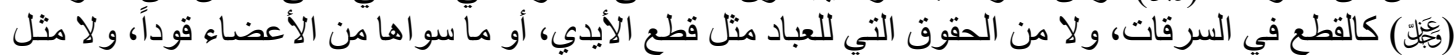

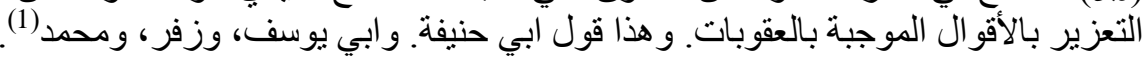

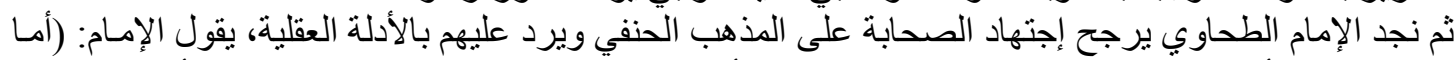

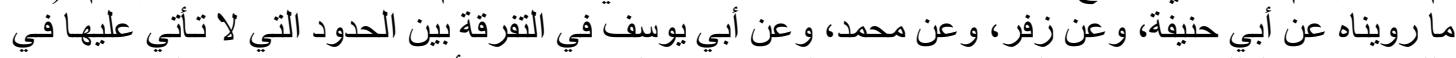

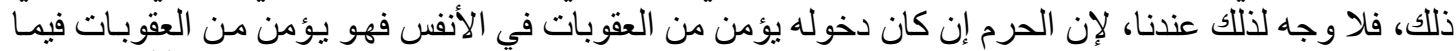

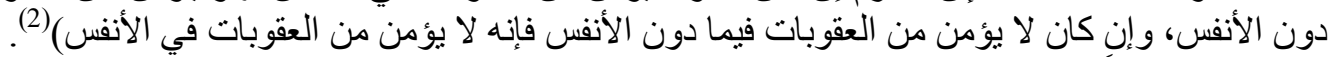

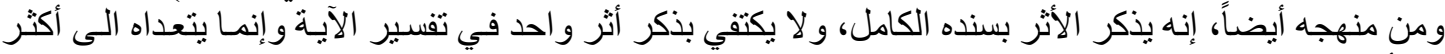

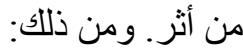

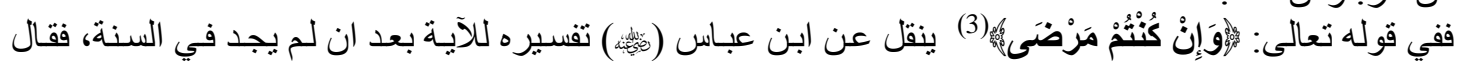

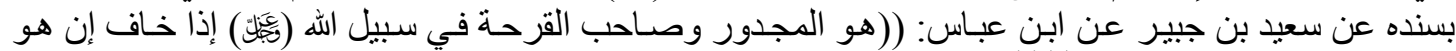

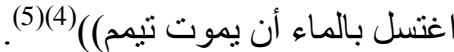

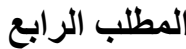

تفسير القرآن بأقوال التابعين

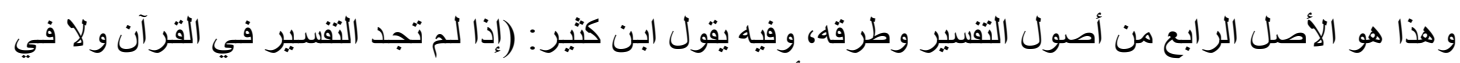

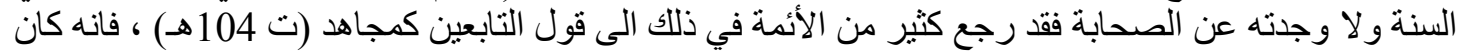

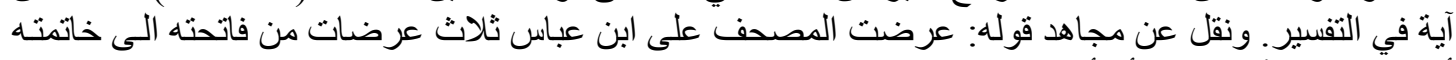

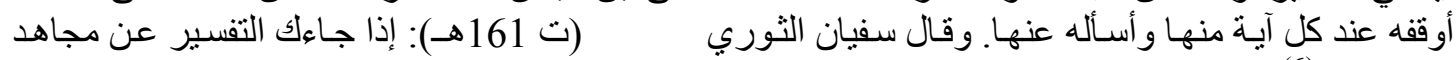

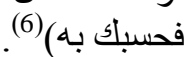

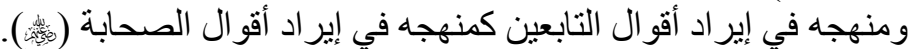

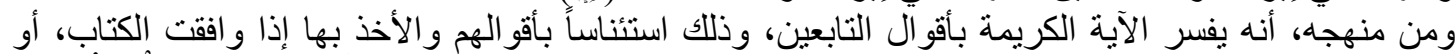

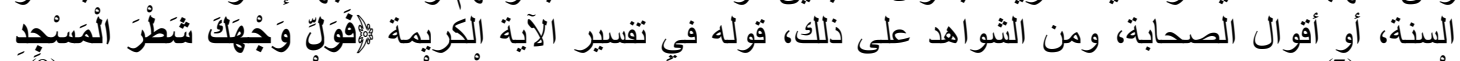

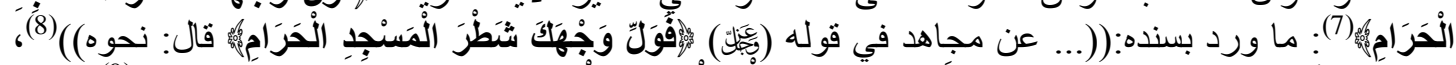

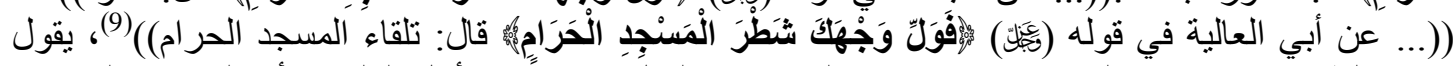

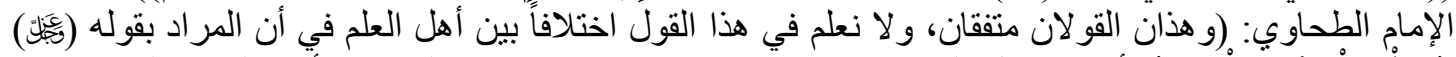

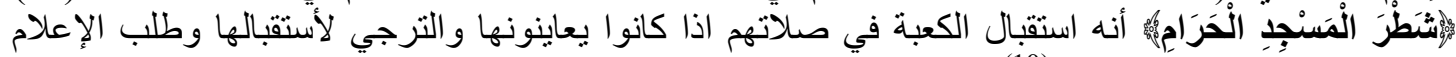

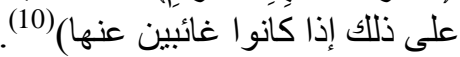

(1) (1) ينظر : المصدر نفسه: 313/2.

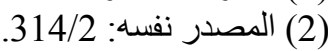

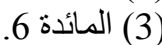

(4) أخرجه الدارقطني، أبو الحسن علي بن عمر بن أحمد بن مهاي بن مسعود بن النعمان بن دينار البغدادي الدارقطني

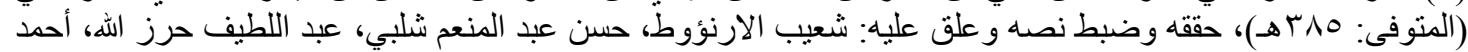

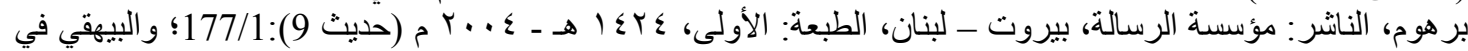

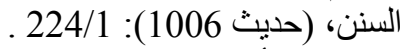

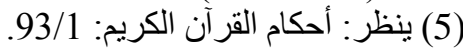

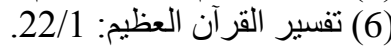

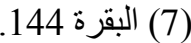

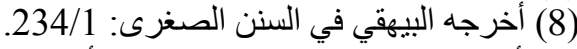

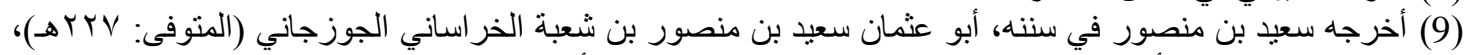

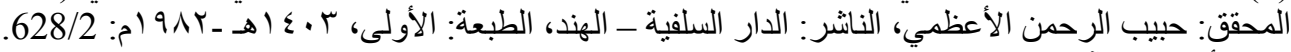

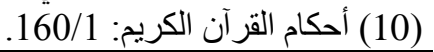




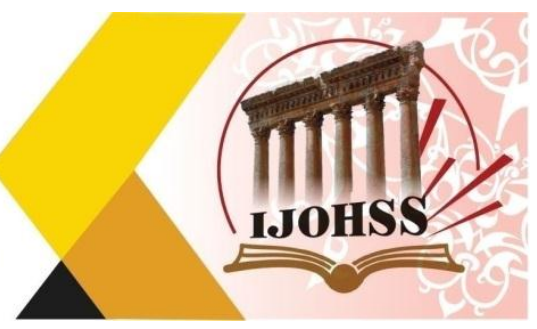

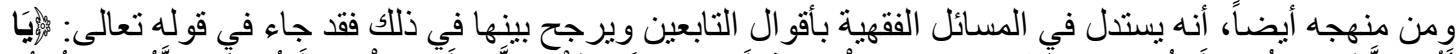

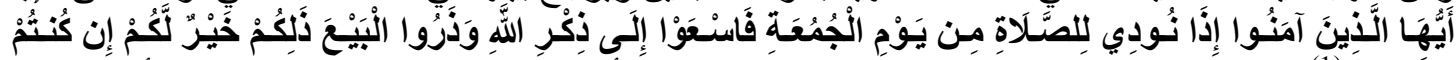

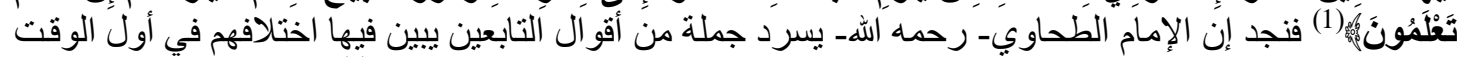

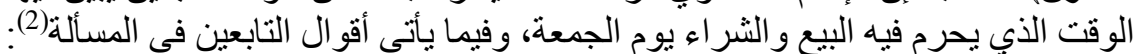

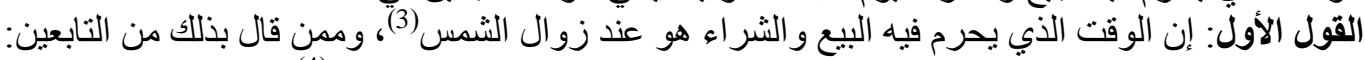

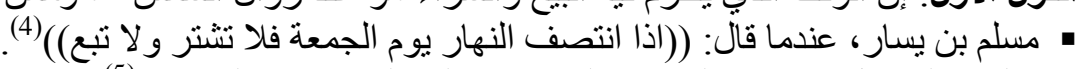

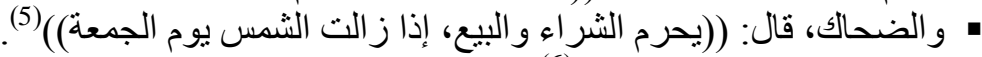

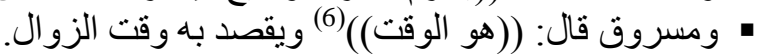

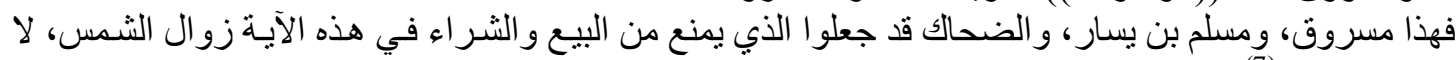
النداء بالصناة:7) (7) (7) القول الثاني: فإن الوقت المحرم هو وقت النداء أب: الأذان للصلاة(8)، وممن قال بذلك من التابعين:

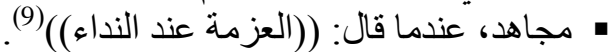

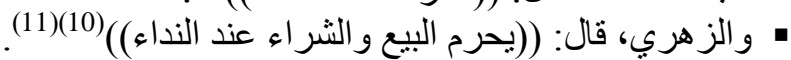

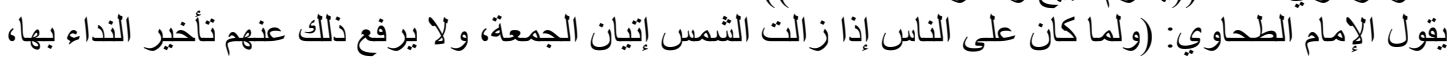

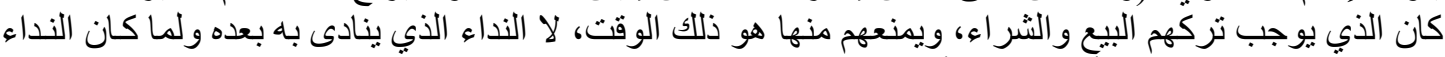

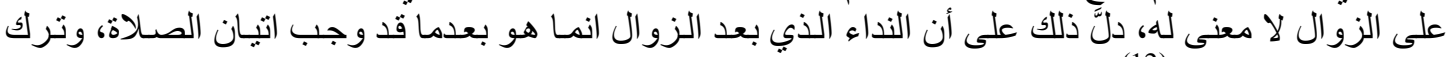
التشاغل عنها بغير ها) (12).

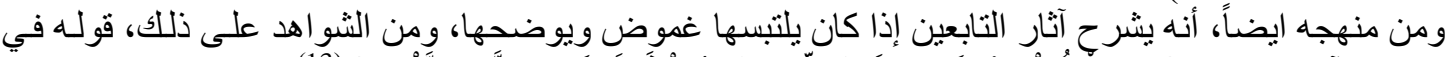

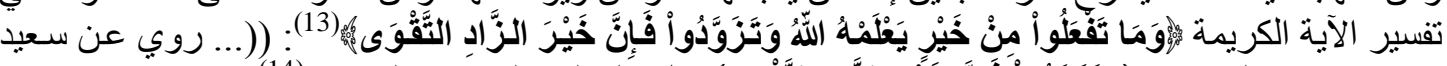

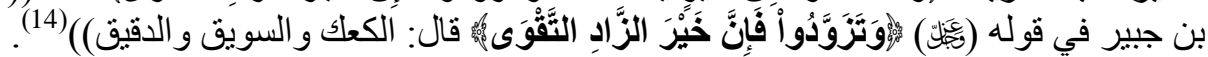

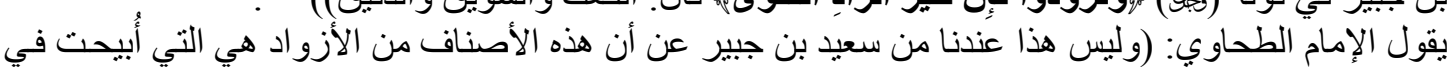

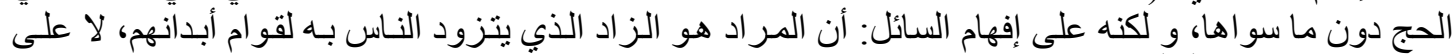

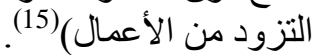

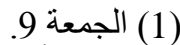

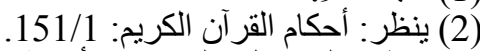

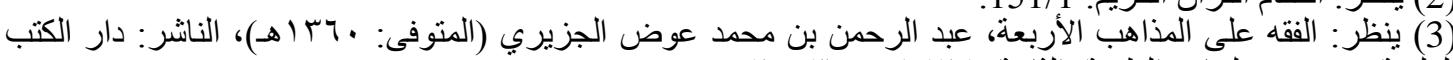

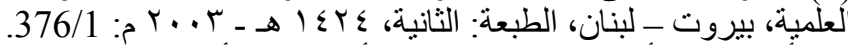

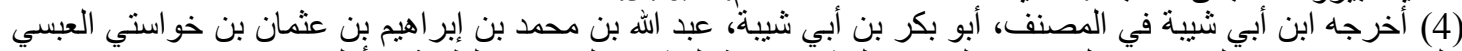

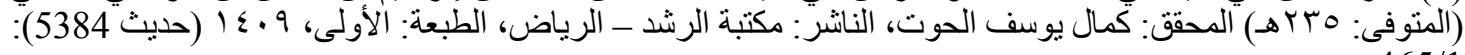
465/1

(5) أخرجه عبد الرزاق في المصنف، أبو بكر عبد الرزاق بن همام بن نافع الحميري اليماني الصنعاني (المتوفى: (ابكهـ)،

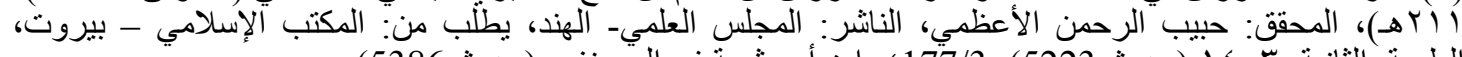

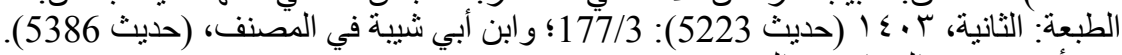

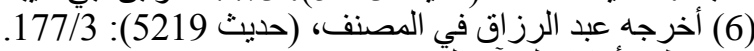

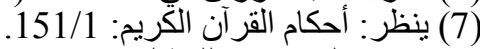

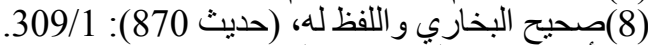

(9) أخرجه عبد الرزاق في الرصنف، (حديث (19) 5218): 176/3.

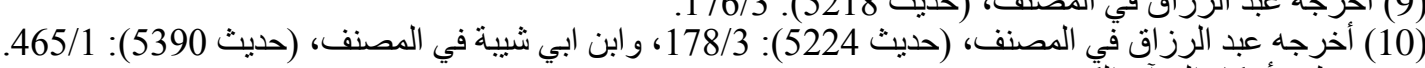

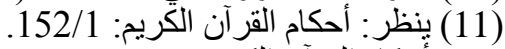

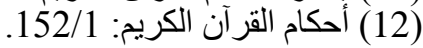

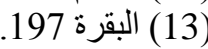
(14) أخرجه ابن أبي شيبة في المصنف: 243/3 وذكره الطبري في تفسبره 280/2 (15) أحكام القرآن الكريم: 36/2. 


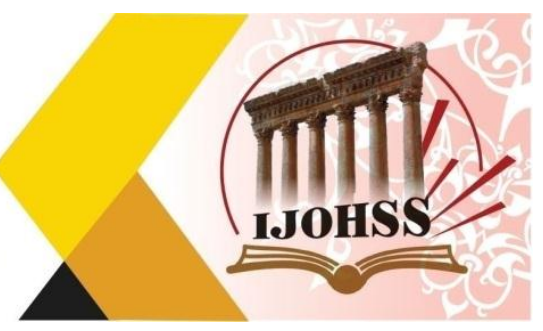

$$
\begin{aligned}
& \text { تفسير القرآن بالرجوع إلى معاني الكلمات في } \\
& \text { اللغة العربية ومدلو لاتها الكانيا }
\end{aligned}
$$

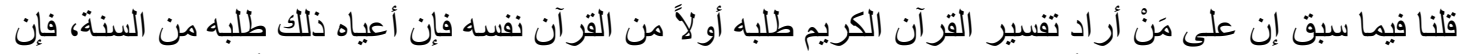

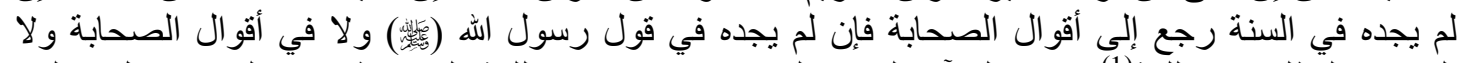

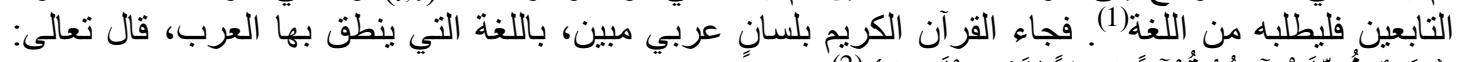

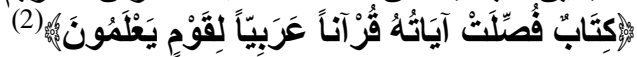

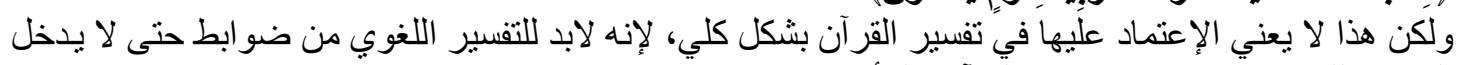
المفسر اللغوي في زمرة من فسر الإنر آلآن بالر أبي.

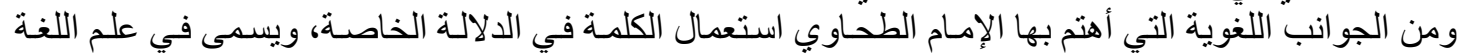

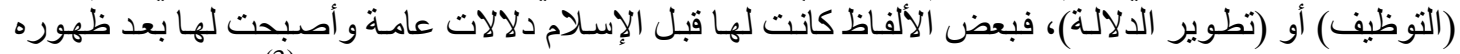

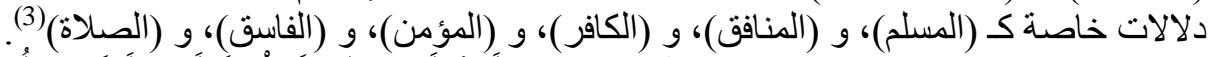

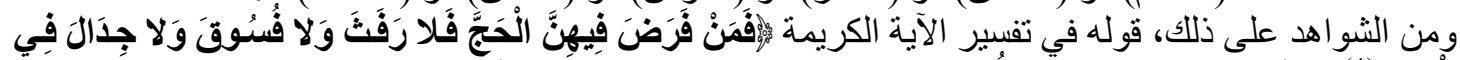

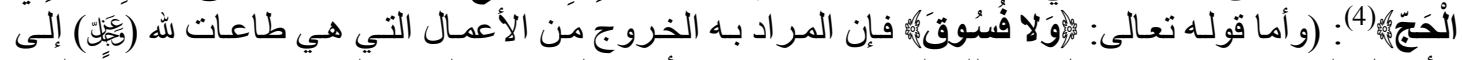

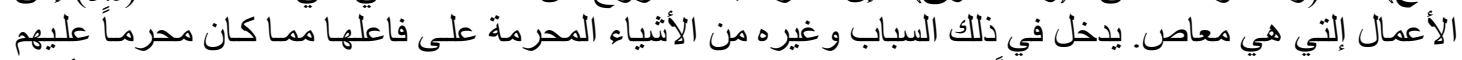

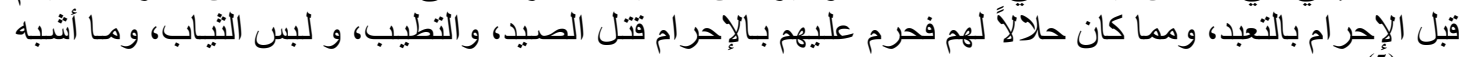
ذلك)(5). (5)

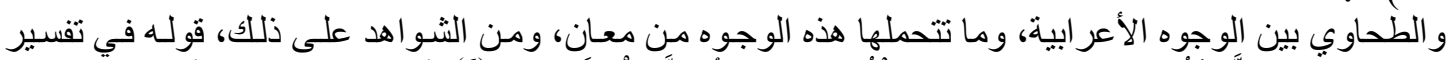

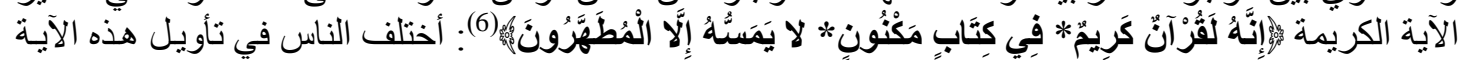

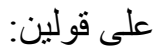
القول الأول: ذهب إلى أن معنى لإنى لا يمسه إلا المطهرون هم الملائكة، واستدلو ا على ذلك مـا ورد بسنده: ((... عن

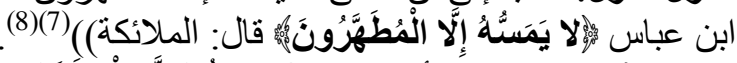

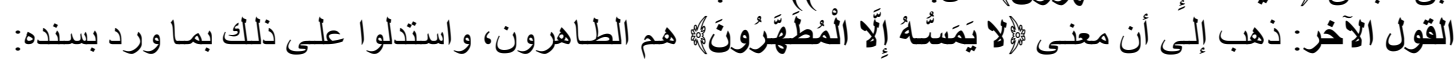

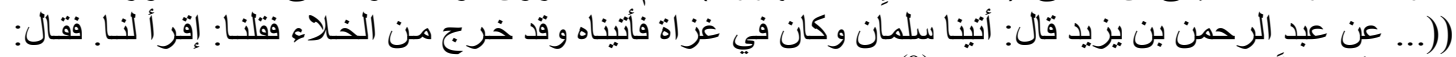

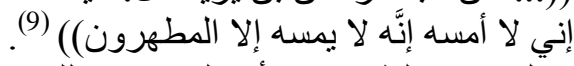

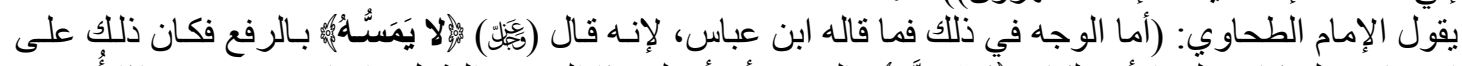

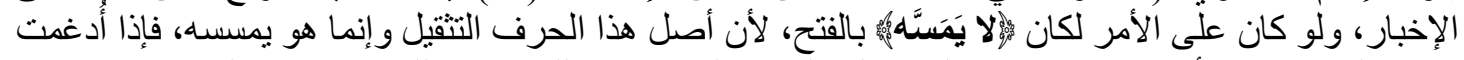

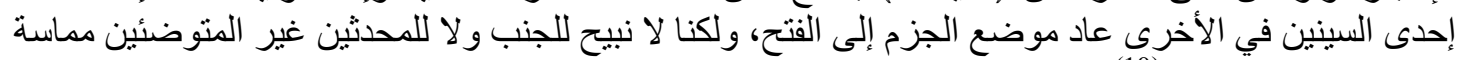
المصحف حتى يتطهر) (10).

(1) (ينظر : أصول التفسير وقو اعده: 79.

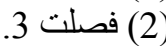

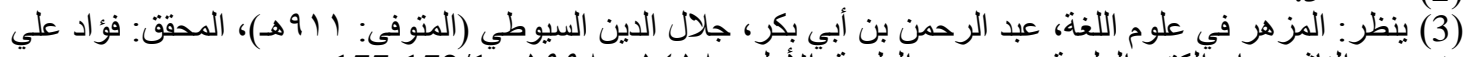

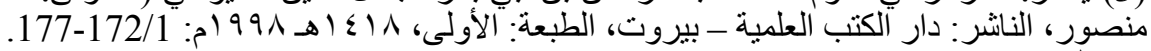

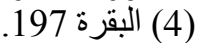

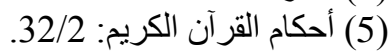

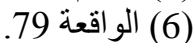
(7) ذكره الطبري في تفسيره، 205/27 من ابن عباس وسعيد بن جبير ، وجابر بن عبد الله و عكرمة ومجاهد و أبي العالية؛

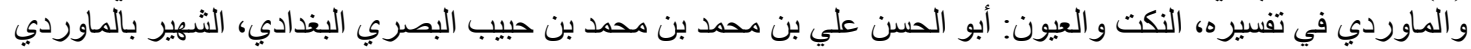

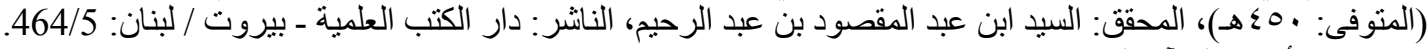




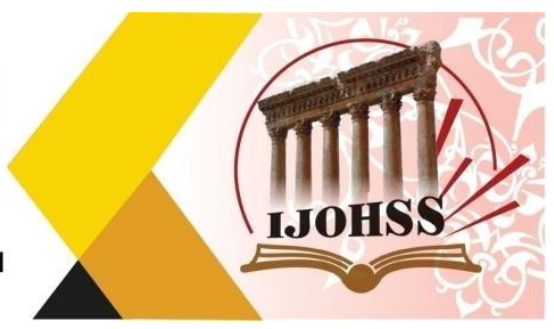

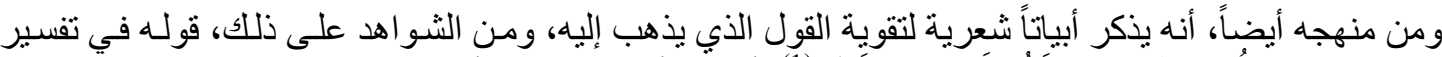

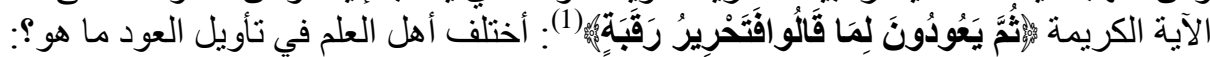

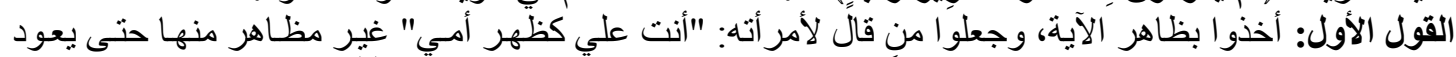

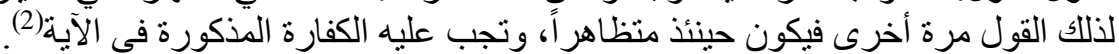

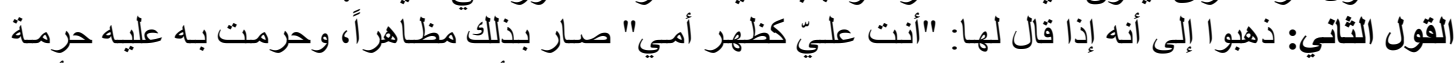

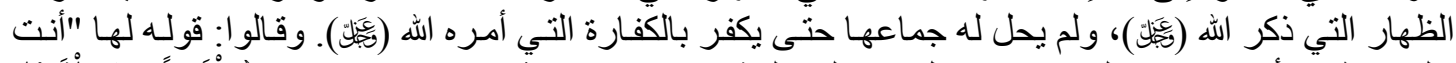

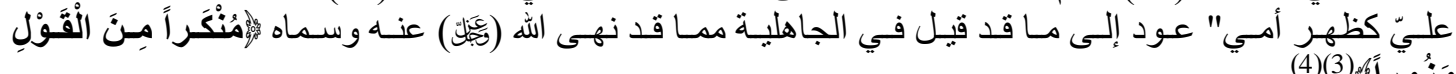

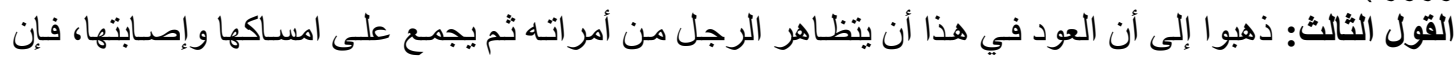

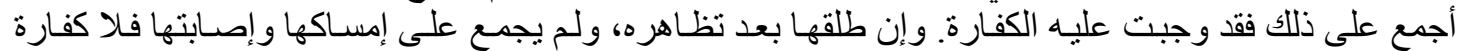

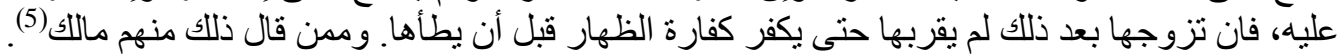

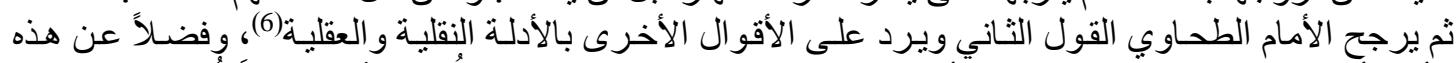

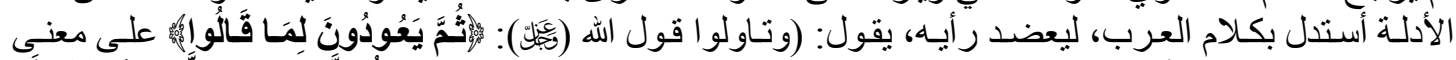

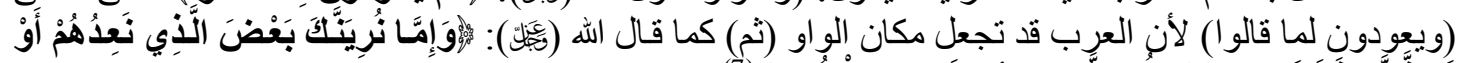

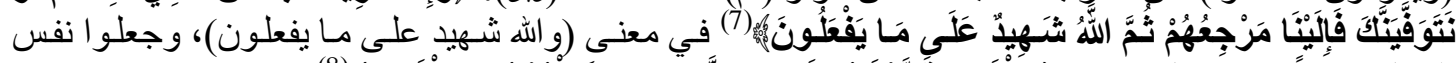

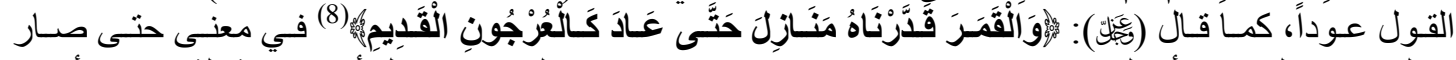

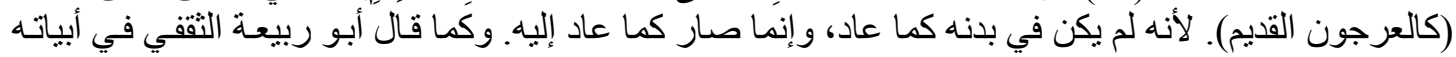

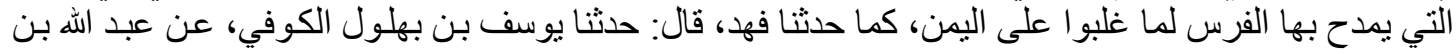

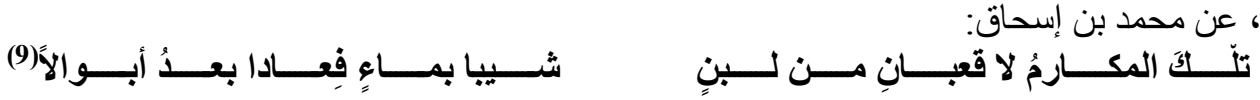

أي فصار ا بعد أبو الاً، لا لانهما كانا في البدو أبو الاً فصارا غير أبو ال ثم عادا بعد أبو الاً بعد ذللك. وهذا القول قد قالَ باه غير و احد من أصحابنا)(10).

الخاتمة

من خلال بحثي الموجز عن الإمام الطحاوي توصلت للنتائج التالية:

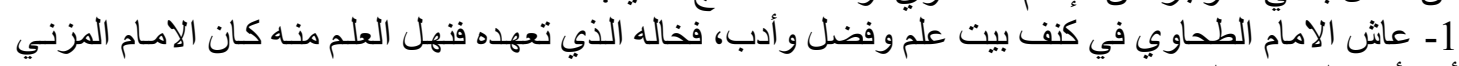
أحد أئمة الثافعية البارزين.

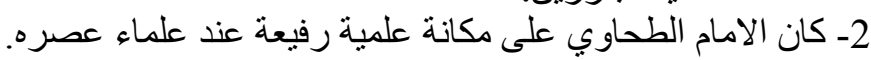

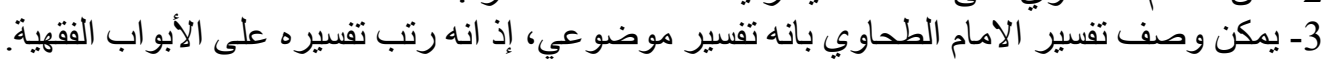

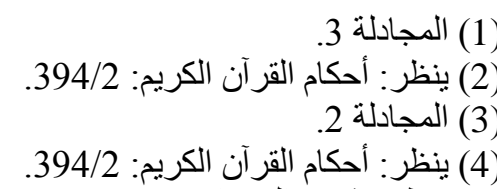

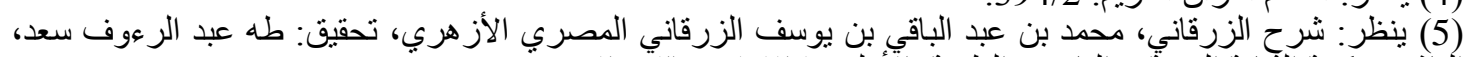

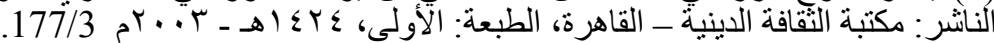
(6) (6نظر : أُحكام القرآن الكريم: 397-396/2.

(7) (7) يونس 46 ين

(9) طبقات فحول الشعر اء، محمد بن سلام الجمي (المتوفى: 232هـ)، المحقق: محمود محمد شاكر، الناثر : دار المدني -

395-394/2. 


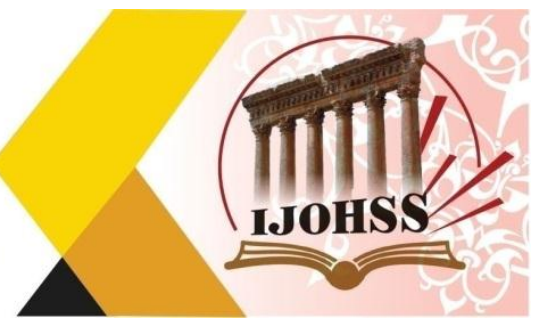

4- عني الإمام الطحاوي بقسم من علوم القر آن، كاسباب النزول، و الناسخ و المنسوخ، و القر اءات القر آنية.

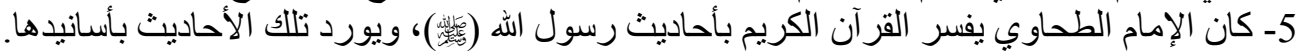

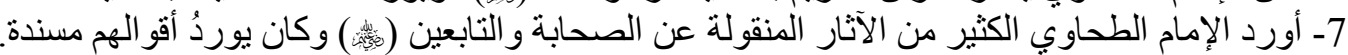

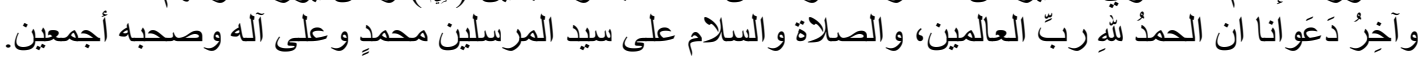

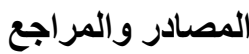
القرآن الكريم

1. أبو جعفر الطحاوي الامام المحدث الفقيه، مؤسسة الرسالة، بيروت ـ لبنان، الطبعة الأولى .

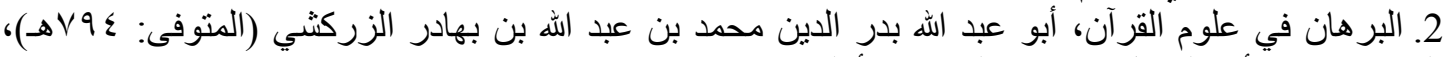

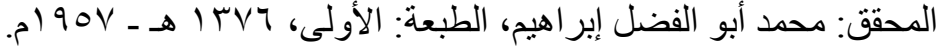

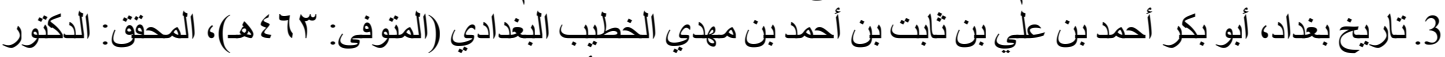

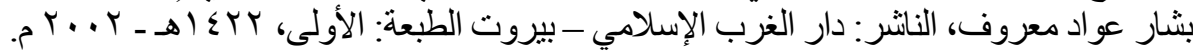

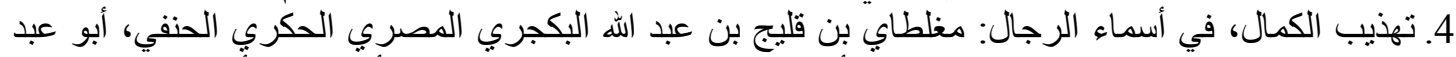

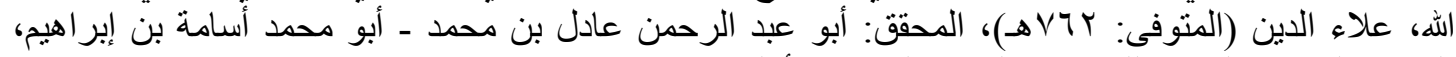

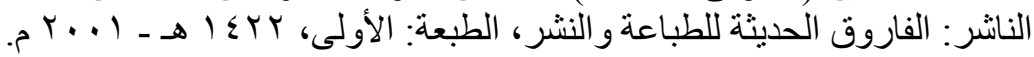

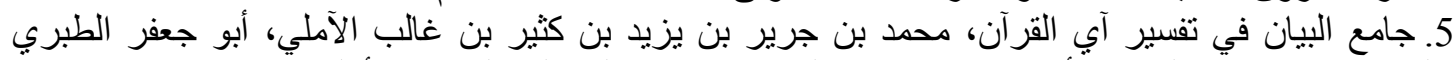

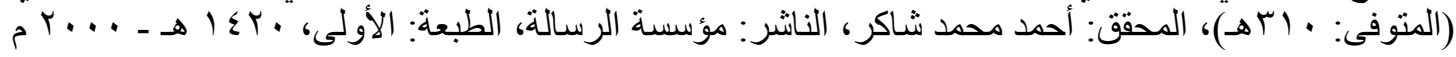

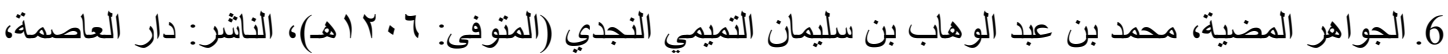

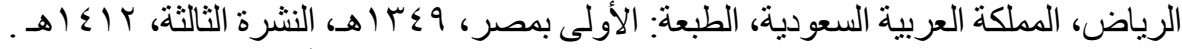

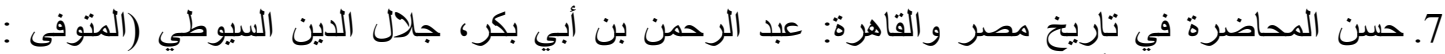

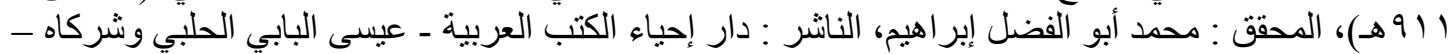

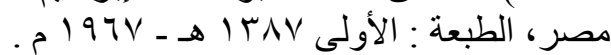

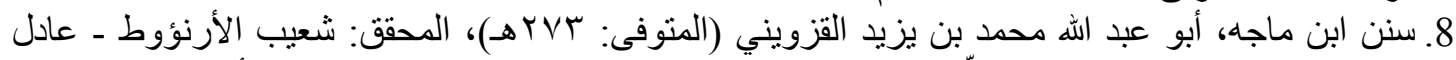

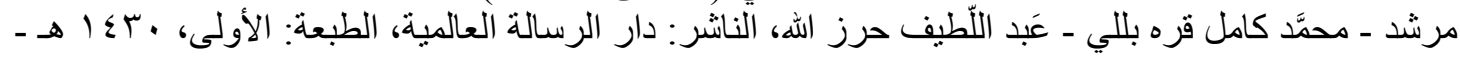
9. سنن البيهقي ، أحمد بن الحسين بن علي بن موسى الخُسْرَوْجِردي الخراساني، أبو بكر البيهقي (المتوفى:

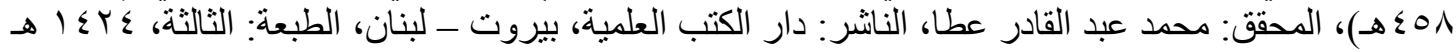

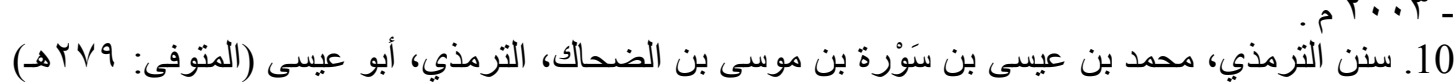
تحقيق وتعليق:أحمد محمد شاكر ، الناشر : شركة مكتبة ومطبعة مصطفى البابي الحلبي ـ مصر ، الطبعة: الثانية،

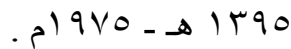

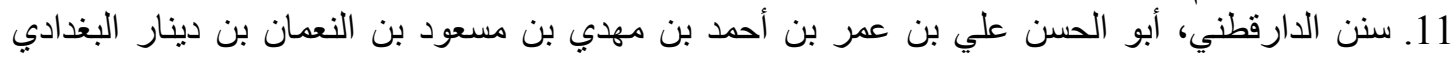

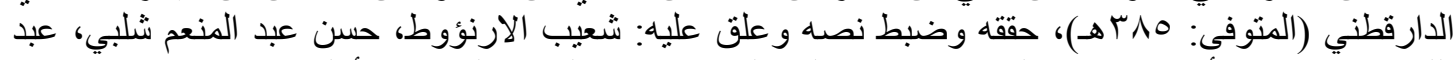

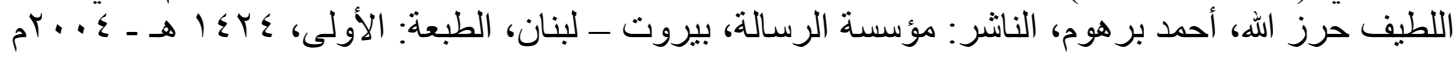

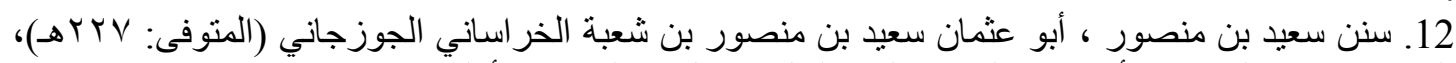

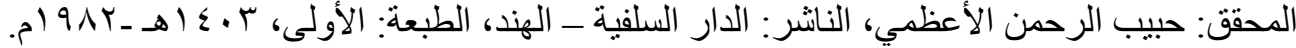

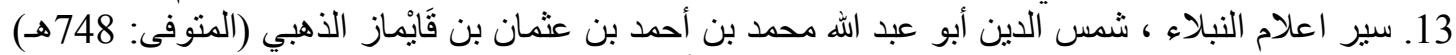

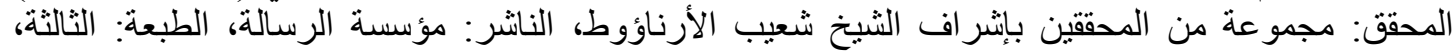

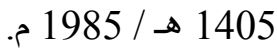


14. شرح الزرقاني، محمد بن عبد الباقي بن يوسف الزرقاني المصري الأزهري تحقيق: طه عبد الرعوف سعد،

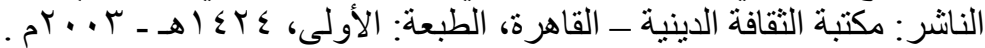

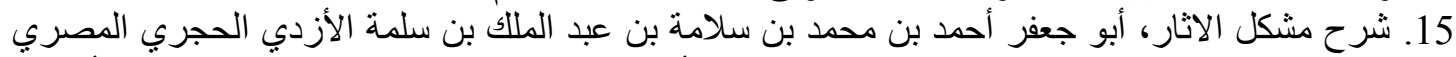

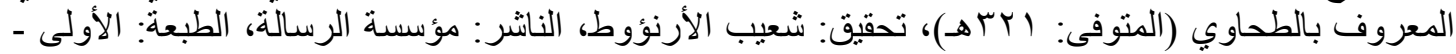

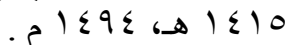

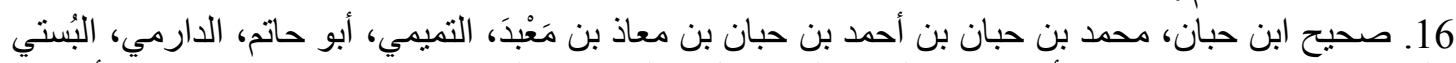

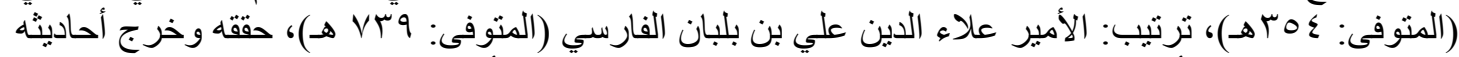

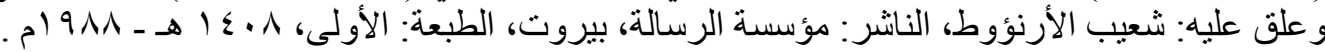

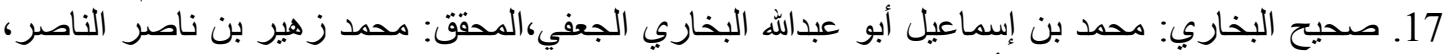

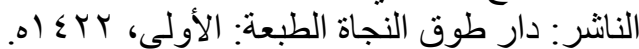

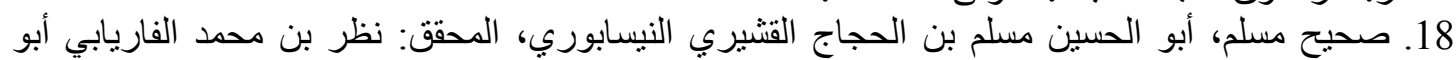

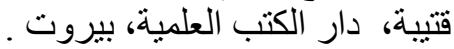

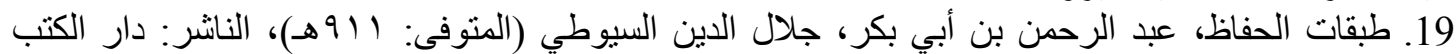

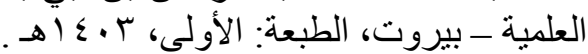

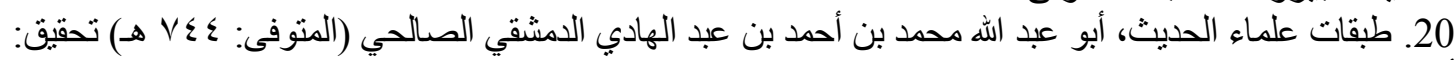

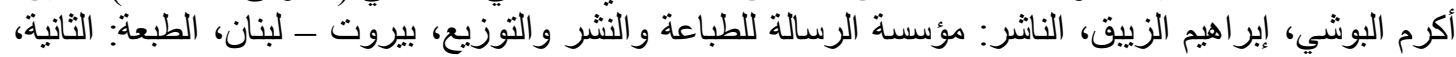

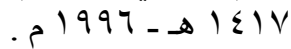
21. طبقات فحول الثعر اء، محمد بن سلام الجمحي (المتوفى: 232هـ)، المحقق: محمود محمد شاكر ، الناثر:

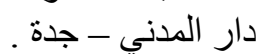
22. فتح ألباري، فتح الباري شرح صحيح البخاري: أحمد بن علي بن حجر أبو الفضل العسقلاني الشافعي،

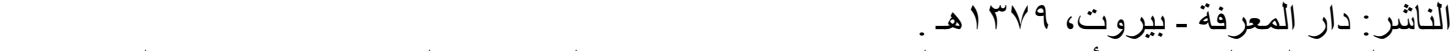

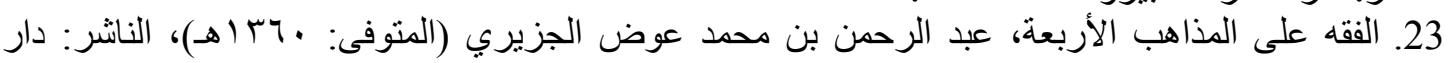

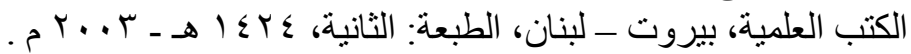

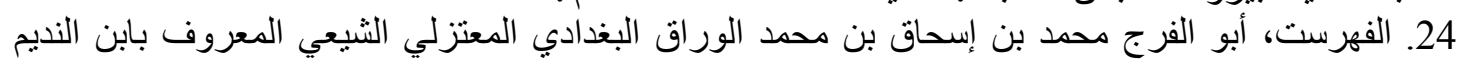

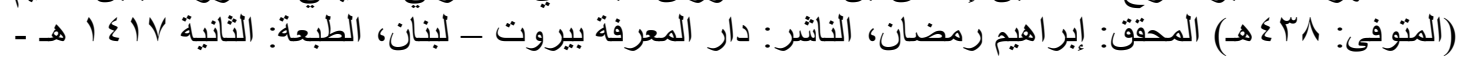
مـ 199V

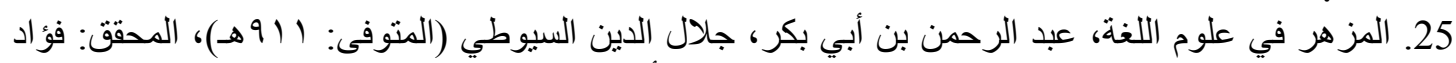

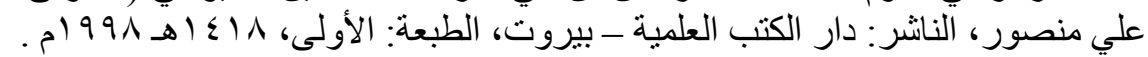

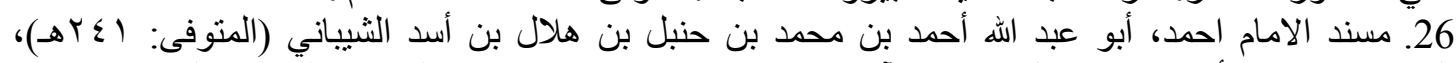

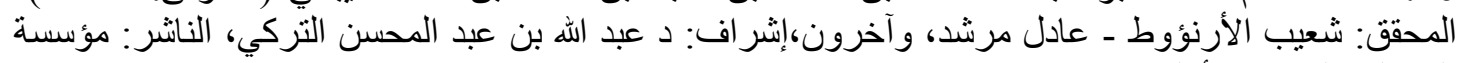

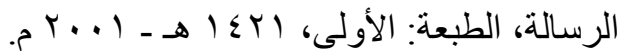

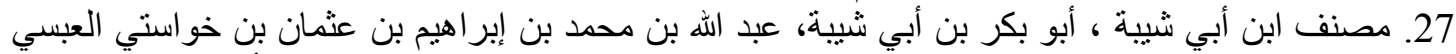

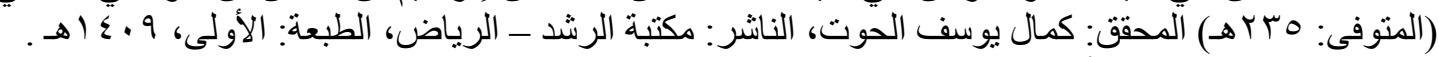

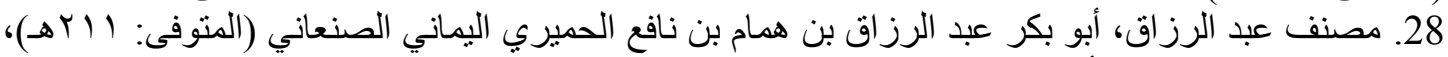

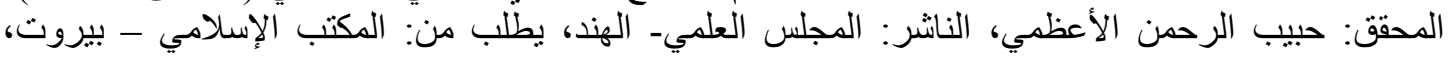

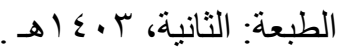

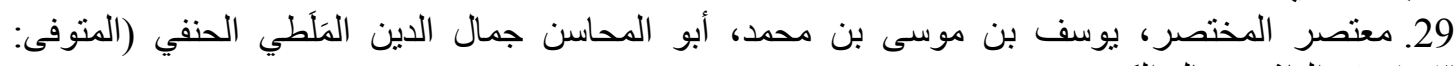

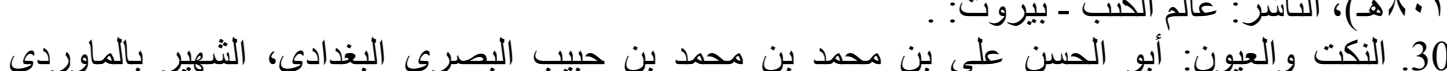

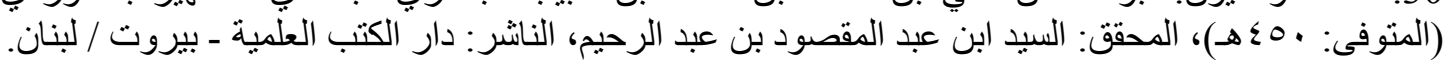

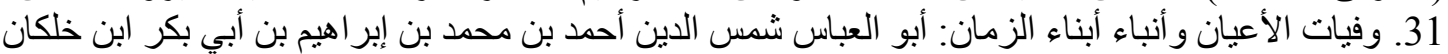

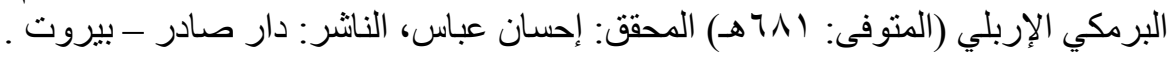

